GEOLOGICAL SURVEY CIRCULAR 734

The Alaskan Mineral Resource Assessment Program: Background Information to Accompany Folio of Geologic and Mineral Resource Maps of the Tanacross Quadrangle, Alaska 
The Alaskan Mineral Resource Assessment Program: Background Information to Accompany Folio of Geologic and Mineral Resource Maps of the Tanacross Quadrangle, Alaska

By H. L. Foster, N. R. D. Albert, D. F. Barnes, G. C. Curtin, Andrew Griscom, D. A. Singer, and J. G. Smith

GEOLOGICAL SURVEY CIRCULAR 734 


\section{United States Department of the Interior}

\section{THOMAS S. KLEPPE, Secretary}

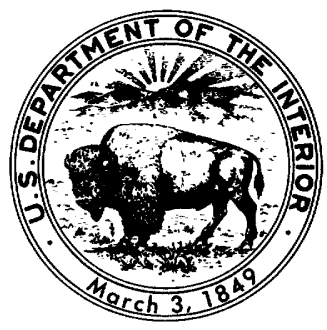

\section{Geological Survey}

V. E. McKelvey, Director

\footnotetext{
Library of Congress Cataloging in Publication Data

Foster, Helen Laura, 1919-

The Alaskan mineral resource assessment program.

(Geological Survey Circular 734)

Bibliography: p. 20

1. Geology-Alaska-Tanacross region. 2. Mines and mineral resources-Alaska-Tanacross region. I. Foster, Helen Laura, 1919- II. Series: United States Geological Survey Circular 734.

QE75.C5 no. 734[QE84.T27] 


\section{CONTENTS}

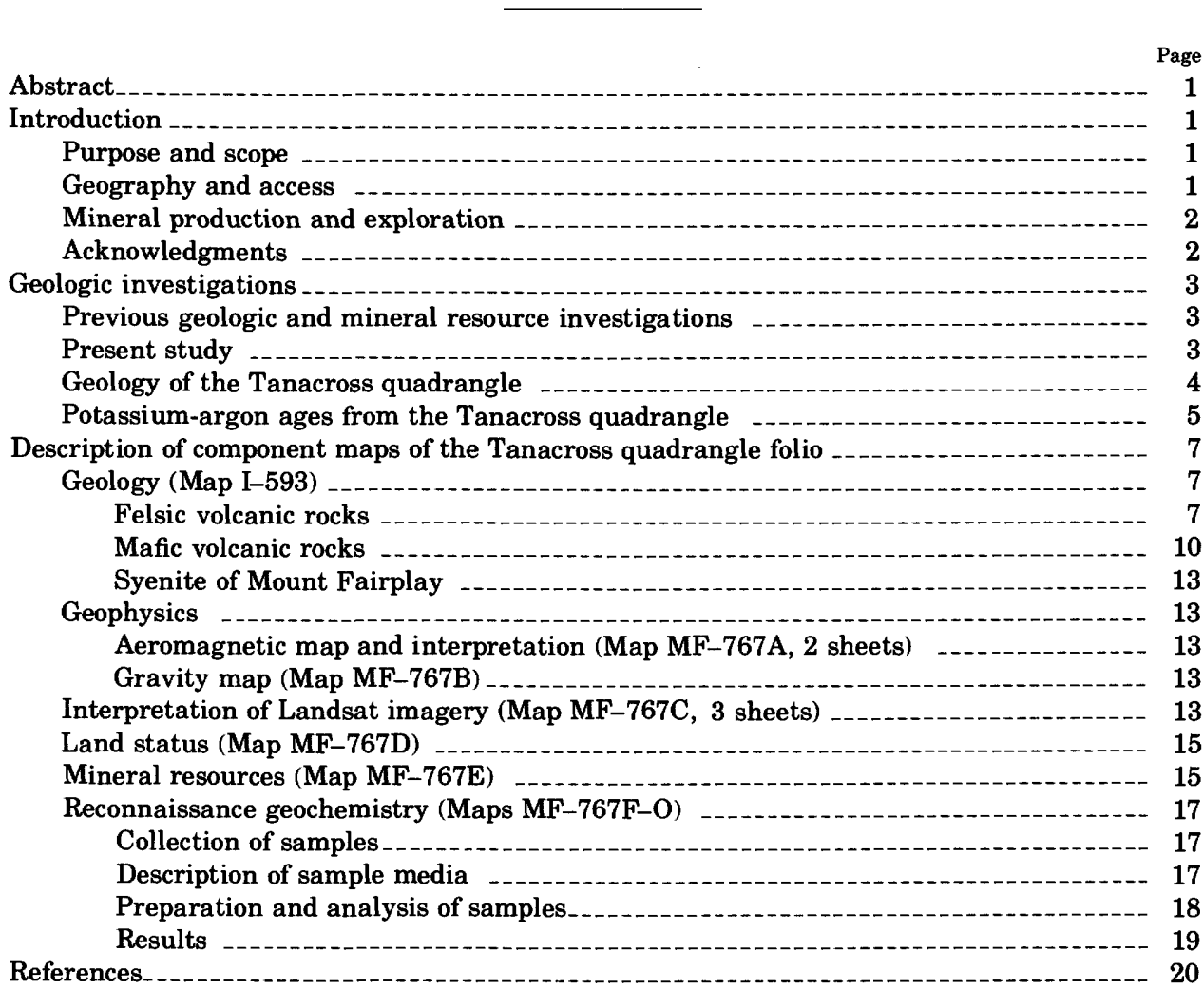

\section{ILLUSTRATIONS}

Figure 1. Index map showing location of Tanacross quadrangle, Alaska

2. Map showing physiographic provinces of the Tanacross quadrangle and its location in relation to major faults

3. Map showing potassium-argon ages of rocks from the Tanacross and southern Eagle quadrangles

4. Index map showing localities where revisions are made to the Reconnaissance Geologic Map of the Tanacross quadrangle, Alaska (Foster, 1970)

5-12. Maps showing:

5. Revisions in the northwest corner of the Reconnaissance Geologic Map of the Tanacross quadrangle, Alaska (Foster, 1970)

6. Revisions in the west-central part of the Reconnaissance Geologic Map of the Tanacross quadrangle, Alaska (Foster, 1970)

7. Revisions in the southwest corner of the Reconnaissance Geologic Map of the Tanacross quadrangle, Alaska (Foster, 1970)

8. Revisions in the north-central part of the Reconnaissance Geologic Map of the Tanacross quadrangle, Alaska (Foster, 1970) 
Figures 5-12. Maps showing-Continued

9. Revisions in the east-central part of the Reconnaissance Geologic Map of the Tanacross quadrangle, Alaska (Foster, 1970)

10. Revisions in the southeastern part of the Reconnaissance Geologic Map of the Tanacross quadrangle, Alaska (Foster, 1970)

11. Revisions in the south-central part of the Reconnaissance Geologic Map of the Tanacross quadrangle, Alaska (Foster, 1970)

12. Revisions in the northeastern corner of the reconnaisance Geologic Map of the Tanacross quadrangle, Alaska (Foster, 1970) 13. Explanation for figures showing corrections to the Reconnaissance Geologic Map of the Tanacross quadrangle, Alaska (Foster, 1970) 16

\section{TABLES}

TABLE 1. Component maps of the Tanacross quadrangle mineral resource assessment 


\title{
The Alaskan Mineral Resource Assessment Program: Background Information to Accompany Folio of Geologic and Mineral Resource Maps of the Tanacross Quadrangle, Alaska
}

\author{
By H. L. Foster, N. R. D. Albert, D. F. Barnes, G. C. Curtin, \\ Andrew Griscom, D. A. Singer, and J. G. Smith
}

\begin{abstract}
The Tanacross quadrangle, consisting of $17,400 \mathrm{~km}^{2}(6,700$ $\mathrm{mi}^{2}$ ) in east-central Alaska, was investigated by an interdisciplinary research team for the purpose of assessing the mineral resource potential of the quadrangle. This report provides the background information for a folio of maps on the geology, geophysics, reconnaissance geochemistry, Landsat imagery, and mineral resource evaluation of the quadrangle. Revisions to the previously published geologic map of the Tanacross quadrangle, 18 new potassium-argon ages, and a comprehensive bibliography are also included.
\end{abstract}

\section{INTRODUCTION}

\section{PURPOSE AND SCOPE}

This circular, together with a separately available folio of maps of the Tanacross quadrangle, Alaska, is one of a series of U.S. Geological Survey reports intended to provide information for formulating a sound long-range national minerals policy to aid in Federal, State, and local landuse planning, to provide significant data for minerals explorations, and to increase the geologic understanding of the area. The work was carried out under the Alaskan Mineral Resource Assessment Program (AMRAP), authorized by Congress to begin on July 1, 1974.

The Tanacross mineral resource assessment consists of this circular, a previously published geologic map, geophysical and geochemical maps, interpretations of satellite imagery, and an analysis of the mineral endowment (table 1). Many of the basic data for this report were collected prior to July 1,1974 . Since then, an interdisciplinary team of scientists has carried on additional field and laboratory studies. The Tanacross quadrangle is the result of a multidisciplinary study and evaluation in a very poorly exposed but highly complex geologic terrane which has had only reconnaissance-type geologic mapping.

\section{GEOGRAPHY AND ACCESS}

The Tanacross quadrangle covers approximately $17,400 \mathrm{~km}^{2}\left(6,700 \mathrm{mi}^{2}\right)$ in east-central

\section{TABLE 1.-Component maps of the Tanacross quadrangle} mineral resource assessment

\begin{tabular}{|c|c|}
\hline Map & Subject \\
\hline $\begin{array}{l}\text { U.S. Geological Survey Miscellaneous } \\
\text { Geological Investigations (I) Map }\end{array}$ & \\
\hline $\begin{array}{c}\text { I-593 (Foster, 1970) } \\
\text { U.S. Geological Survey Miscellaneous } \\
\text { Field Studies }(M F) \text { Map }\end{array}$ & Reconnaissance geology. \\
\hline $\begin{array}{l}\text { MF-767-A (Griscom, 1976) } \\
\text { B (Barnes, 1976) } \\
\text { C ( (Albert and Steele, 1976) } \\
\text { D (Dusel, 1976) } \\
\text { E (Singer and others, 1976) } \\
\text { G (Curtin and others, 1976a) (Curtin and others, 1976b) } \\
\text { H (Curtin and others, 1976c) } \\
\text { I (Curtin and others, 1976d) } \\
\text { J (Curtin and others, 1976e) } \\
\text { K (Curtin and others, 1976f) } \\
\text { L (Curtin and others, 1976g) } \\
\text { M (Curtin and others, 1976h) } \\
\text { N (Curtin and others, 1976i) } \\
\text { O (Tripp and others, 1976) }\end{array}$ & $\begin{array}{l}\text { Aeromagnetic map and inter- } \\
\text { pretation. } \\
\text { Gravity map. } \\
\text { Interpretations of satellite } \\
\text { imagery. } \\
\text { Land status. } \\
\text { Mineral resources. } \\
\text { Geochemical distribution and } \\
\text { abundance of copper. } \\
\text { Geochemical distribution and } \\
\text { abundance of molybdenum. } \\
\text { Geochemical distribution and } \\
\text { abundance of lead. } \\
\text { Geochemical distribution and } \\
\text { abundance of zinc. } \\
\text { Geochemical distribution and } \\
\text { abundance of arsenic and } \\
\text { mercury. } \\
\text { Geochemical distribution and } \\
\text { abundance of tin. } \\
\text { Geochemical distribution and } \\
\text { abundance of beryllium. } \\
\text { Anomalous distribution of } \\
\text { copper and molybdenum. } \\
\text { Anomalous distribution of } \\
\text { lead and zinc. } \\
\text { Mineralogical and geochemi- } \\
\text { cal data for heavy-mineral } \\
\text { concentrates. }\end{array}$ \\
\hline
\end{tabular}




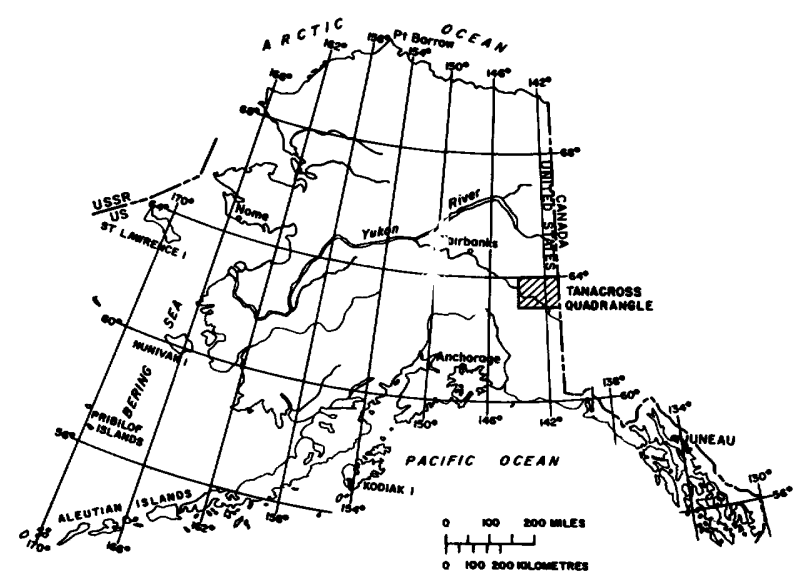

Figure 1.-Location of Tanacross quadrangle, Alaska.

Alaska (fig. 1) between lat $63^{\circ}$ and $64^{\circ} \mathrm{N}$. and long $141^{\circ}$ and $144^{\circ} \mathrm{W}$. Three major physiographic provinces are included in the quadrangle: the rugged glaciated mountains of the eastern part of the Alaska Range, the plains and low rolling hills of the Northway-Tanacross Lowland, and the unglaciated, maturely dissected mountains of the Yukon-Tanana Upland (fig. 2) (Wahrhaftig, 1965). Drainage is into the Tanana River, tributaries to the Fortymile River, and the Ladue River, all of which are directly or indirectly tributary to the Yukon River.

Elevations range from approximately $2,267 \mathrm{~m}$ $(7,438 \mathrm{ft})$ above sea level in the Alaska Range to approximately $466 \mathrm{~m}(1,530 \mathrm{ft})$ in the Northway-Tanacross Lowland. Elevations in the Yukon-Tanana Upland range from about $520 \mathrm{~m}$ $(1,700 \mathrm{ft})$ to $1,689 \mathrm{~m}(5,541 \mathrm{ft})$, Mount Fairplay being the highest point in the Yukon-Tanana Upland part of the Tanacross quadrangle.

The Alaska Highway crosses the southern third of the quadrangle in a northwesterly direction, and the Glenn Highway, from Anchorage, joins it at Tok. The Taylor Highway extends northward from Tetlin Junction through the east third of the quadrangle. The Taylor Highway, an all-weather gravel road, is generally closed during the winter months.

\section{MINERAL PRODUCTION AND EXPLORATION}

There has been no mineral production from the Tanacross quadrangle except for the quarrying of sand, gravel, fill, and other road building materials, used locally, and a small amount of ornamental building stone (Richter, 1967, p. 19).

A small amount of antimony was mined on

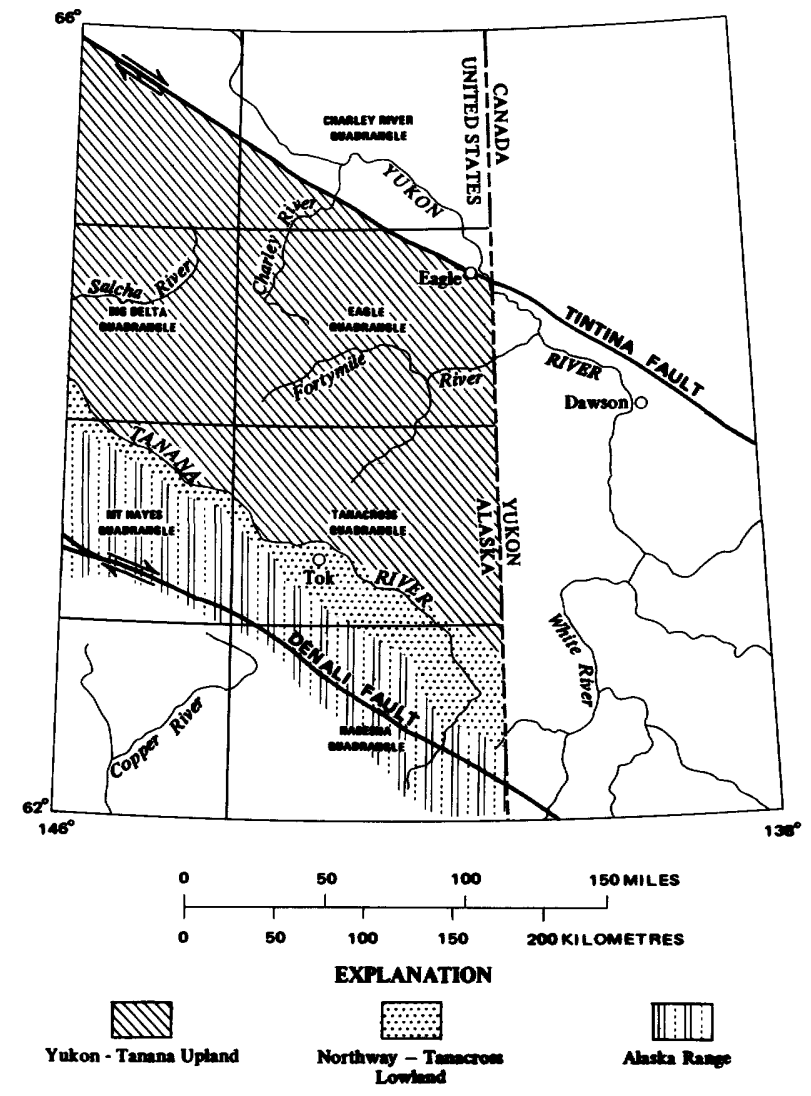

FIGURE 2.-Physiographic provinces of the Tanacross quadrangle and its location in relation to major faults.

Stibnite Creek in 1941 but was never transported from the area (Moffit, 1954, p. 207-208). Mining was also attempted there more recently without any significant production.

There has been considerable exploration for porphyry copper deposits since the late 1960's, and several localities have been drilled; as yet, there has been no development.

In 1975 gold placer claims were staked in the southeast corner of the quadrangle on tributaries to McArthur Creek after promising placer gold discoveries had been made nearby in the Yukon Territory. Although the gold potential of this area is uncertain, careful prospecting in previous years has not produced any significant finds on the Alaskan side of the border.

Commercial deposits of oil, gas, and coal are not known in the Tanacross quadrangle, and the likelihood of occurrence of these commodities is small.

\section{ACKNOWLEDGMENTS}

Many scientists have participated and contributed to the geologic mapping of the Tanacross 
quadrangle. Also much assistance was given by local Alaskans and by U.S. Army and commercial helicopter crews. The assistance of some of these is acknowledged on the geologic map (Foster, 1970) and in Foster (1967, p. B-2).

In the AMRAP field phase of the project special thanks are due Gerald Timmons, former Area Regional Manager of the Forty Mile Resource Area, Bureau of Land Management (BLM), and others at BLM Tanacross. Fortymile Air Service rendered invaluable assistance on many occasions. Special thanks and commendation are given to the late Dale Hefter of Hosking Helicopters Inc. for an exceptionally skillful job as helicopter pilot in the summer of 1974. Geologists from several mining companies have given assistance in the field and office and offered useful information.

The able and cheerful assistance of Alice $\mathbf{M}$. Cantelow in the field and office and of Cynthia Dusel and Frances Wahl on processing manuscripts is much appreciated. Martha Yount helped in preparing the bibliography, using computer-assisted methods, and Frederick Wilson assisted in organizing the data on potassium-argon ages. Henry Berg, coordinator of AMRAP, has given continual assistance and guidance throughout the project.

\section{GEOLOGIC INVESTIGATIONS \\ PREVIOUS GEOLOGIC AND MINERAL RESOURCE INVESTIGATIONS}

Lieutenant H. T. Allen initiated scientific observations and mapping in the Tanacross quadrangle on his remarkable traverse across the eastern Alaska Range and down the Tanana River from the mouth of the Tok River to the Yukon in 1885 for the U.S. War Department (Allen, 1887). Allen made the first reliable map of the Tanana River. The first geologic expedition into the Tanacross quadrangle was that of $\mathrm{A}$. $\mathrm{H}$. Brooks and W. J. Peters in 1898 when they ascended the White River, portaged to the headwaters of the Tanana River, and descended the Tanana to its confluence with the Yukon (Brooks, $1900 \mathrm{~b})$. Also in 1899 Brooks traversed the quadrangle from south to north enroute to Eagle from Lynn Canal (Brooks, 1900a).

Systematic geologic study of the YukonTanana Upland was undertaken in 1903 by L. M. Prindle with other U.S.G.S. geologists, and in 1905 Prindle made a lengthy traverse in the
Tanacross quadrangle (Prindle, 1909). J. B. Mertie, Jr., continued the geologic work in the Yukon-Tanana Upland and made a traverse in the Tanacross quadrangle in 1928. Mertie (1937) compiled the available geologic information on the Yukon-Tanana Upland, and this report has served as the basis for all further geologic work and is still the principal reference on parts of the upland.

While Mertie was working in the upland, F. H. Moffit was carrying out geologic reconnaissance in the Alaska Range. His comprehensive summary report on the eastern part of the Alaska Range (Moffit, 1954) has long been the principal reference for that part of the Tanacross quadrangle in the Alaska Range.

\section{PRESENT STUDY}

Field and laboratory work for the present study has been carried out intermittently since 1961 . From 1961 to 1964, some geologic reconnaissance work done by the U.S. Geological Survey in cooperation with the Office of the Engineer, U.S. Army, and the Defense Intelligence Agency resulted in the publication of a geologic map of the Tanacross C-3 and D-3 quadrangles (Foster, 1967): In 1967 geologic reconnaissance mapping and a limited amount of geochemical sampling were accomplished. This work, combined with that done earlier in the decade, was published on the 1:250,000-scale reconnaissance geologic map of the Tanacross quadrangle (Foster, 1970), which is also part of this study and that by Clark, Condon, Foster, and Hoare (1969).

The aeromagnetic map of the Tanacross quadrangle that is used for aeromagnetic interpretation in this study was compiled from a survey flown in 1971 for the State of Alaska Division of Geological and Geophysical Surveys (1973).

In July and August of 1974 a helicopter-supported geochemical reconnaissance was made of the quadrangle, rock samples were collected for potassium-argon age determinations, and some additional geologic observations were made. More than 1,000 samples, including stream sediments, rocks, vegetation, and heavy-mineral concentrates were analyzed by six-step semiquantitative spectrographic analyses and some by wet-chemical methods during the summer and following months. Eighteen new potassium-argon ages were determined on rocks from the Tanacross quadrangle, and minor revisions were made to the geologic map. 


\section{GEOLOGY OF THE TANACROSS QUADRANGLE}

The Tanacross quadrangle is underlain primarily by a complex group of metamorphic rocks that have been intruded by Mesozoic and Tertiary granitic rocks and locally covered by volcanic rocks. The Denali fault, a major active dextral fault that crosses the southwesternmost corner of the quadrangle, separates this metamorphic terrane from a relatively unmetamorphosed Paleozoic and Mesozoic terrane to the south. The rocks south of the fault are contiguous with those of the Nabesna quadrangle and are described by Richter (1975). The metamorphic terrane underlies all three physiographic provinces of the Tanacross quadrangle: the Alaska Range, the Northway-Tanacross Lowland, and the YukonTanana Upland (fig. 2).

In the Alaska Range, the metamorphic grade increases from low greenschist facies in the south to amphibolite facies in the north (Foster, 1970). Metamorphic rocks in the Yukon-Tanana Upland are predominantly amphibolite facies but include rocks of greenschist facies. They were derived from both sedimentary and igneous parent rocks and include phyllite, greenstone, quartz-chlorite schist, quartz-mica-chlorite-epidote schist, quartz-mica schist, quartz-mica-garnet schist, quartzite, quartz-biotite gneiss, quartz-biotitegarnet-staurolite schist, augen gneiss, amphibolite, and recrystallized limestone. Recrystallized limestone that contains middle Devonian rugose and tabulate corals (Richter, 1975) in the northern part of the Nabesna quadrangle appears to be on strike with slightly metamorphosed limestone layers in the southern part of the Tanacross quadrangle. This relation suggests that at least some of the metamorphosed sedimentary rocks in the Tanacross quadrangle are Devonian in age, but no other age data from fossils are available.

The metamorphic rocks in the Alaska Range are intruded by dikes, sills, and small bodies of diorite and more mafic rock. The diorite has been altered and perhaps slightly metamorphosed. Grantitic intrusions are small and sparse in the Alaska Range. The largest one occurs near Yerrick Creek and is Late Cretaceous in age (fig. 3 and table 2, No. 12).

The metamorphic rocks of the Yukon-Tanana Upland are extensively intruded by granitic plutons of mostly quartz monzonitic to granodioritic composition. The oldest intrusion, probably Late Triassic or Early Jurassic in age, is the Taylor Mountain batholith in the northern part of the
Tanacross quadrangle and southern part of the Eagle quadrangle (fig. 3; table 2, Nos. 2, 3). The other large intrusions are probably middle Cretaceous in age. The Mount Fairplay pluton is a complex Tertiary intrusion ranging in composition from syenite to granodiorite and quartz monzonite. Shallow felsic porphyritic intrusions, mostly hydrothermally altered, are probably of Tertiary age.

Volcanic rocks crop out in less than 10 percent of the quadrangle, but many may be associated with the igneous activity responsible for much of the mineralization. Felsic tuff, including welded tuff, is abundant, particularly in the area surrounding Mount Fairplay and on Sixtymile Butte. Some of the felsic tuff is associated with the shallow porphyritic felsic intrusive rocks and in most places so intimately associated that they were not mapped separately but were included together in the felsic tuff. Most of the tuff is hydrothermally altered, and original textures and compositions commonly are difficult to impossible to determine. Small areas of more mafic tuff also occur. The volcanic rocks are tentatively considered Tertiary in age, but some in the vicinity of Mount Fairplay may be of Cretaceous age. There are also several areas of basaltic volcanic rocks of probable Tertiary and Pleistocene age and, in addition, the very young Holocene volcanic cone, Prindle Volcano. Prindle Volcano is of special interest because peridotite and granulite inclusions occur in the basaltic lava (Foster and others, 1966).

The only sedimentary rocks present in the Tanacross quadrangle north of the Denali fault are nonmarine conglomerate, sandstone, shale, tuffaceous shale, and tuff of Late Cretaceous or early Tertiary age and Tertiary gravels that lie unconformably on metamorphic rocks (Foster, 1967, p. B6).

The metamorphic rocks of the Tanacross quadrangle are part of a metamorphic complex that lies between the Denali fault and the Tintina fault (fig. 2). These rocks are complexly folded and faulted, but little is known of their structural and metamorphic history. The number of metamorphic episodes, for example, is unknown. However, it is clear that regional metamorphism occurred before the emplacement of the Taylor Mountain batholith in Late Triassic or Jurassic time, because well-foliated metamorphic rocks are incorporated in the nonfoliated granitic rock along the southern margin of the batholith. Foster and 


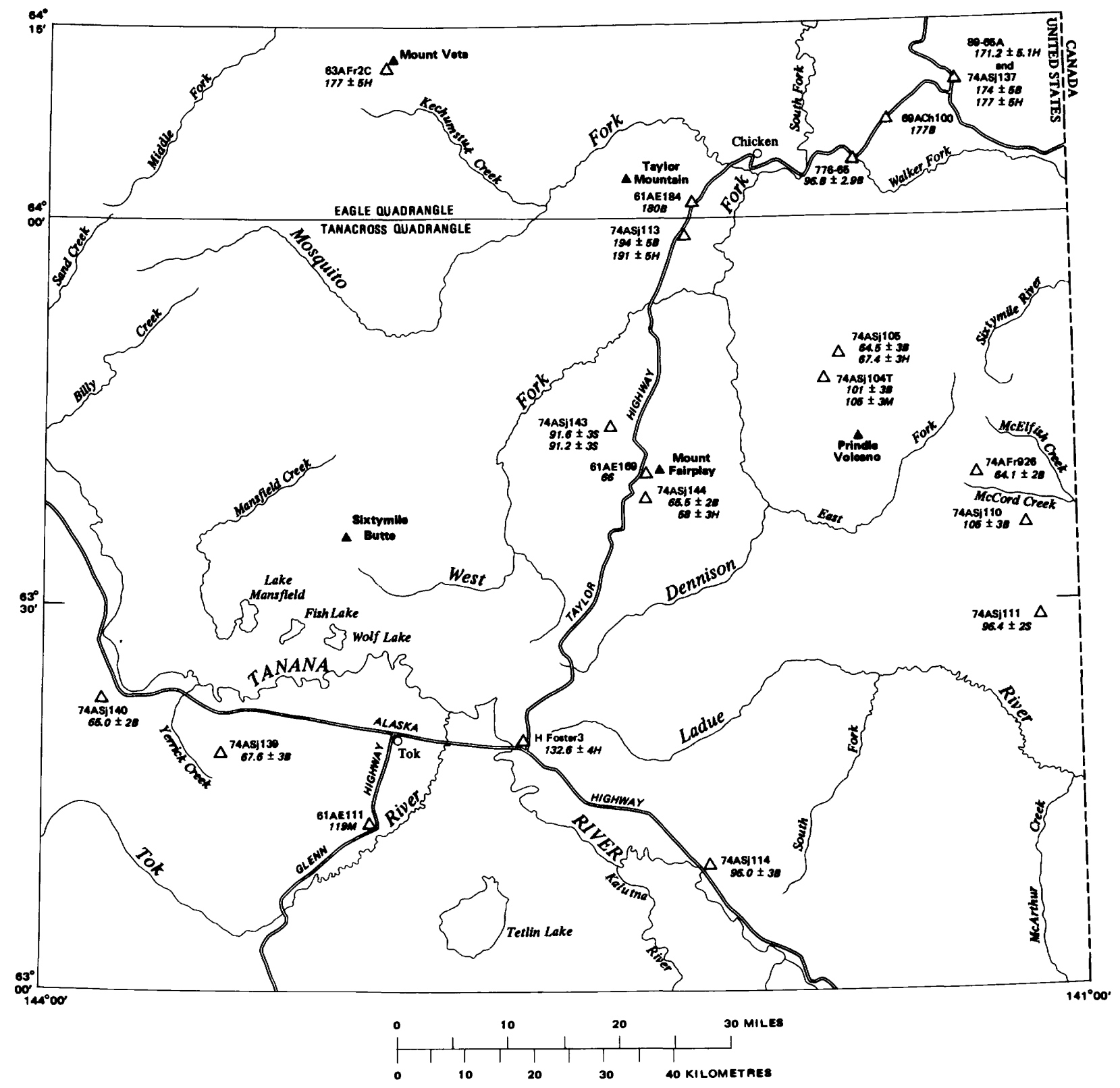

EXPLANATION

$\triangle$ 74ASj140

Locality and locality number
$00 \pm 2$

Age in m.y. and mineral dated (o, biotito; $\dot{H}$, hornblondo; $M$, muscovito; $s$, sonidino)

Figure 3.-Potassium-argon ages of rocks from the Tanacross and southern Eagle quadrangles.

Keith (1974) have proposed that the entire metamorphic terrane is an allochthonous slice of continental material that has moved northward. Tempelman-Kluit, Gordey, and Reed (1976, p. 103-105) also postulate that the metamorphic terrane is allochthonous and suggest that it consists of a metamorphosed Paleozoic eugeosynclinal sequence that overlies an autochthonous miogeosynclinal succession.
POTASSIUM-ARGON AGES FROM THE TANACROSS QUADRANGLE

Eighteen new potassium-argon age determinations for 12 different rocks were made as a part of AMRAP, with emphasis on identifying the principal times of mineralization. When added to ages determined by others, a total of 26 potassium-argon ages is available on rocks from units in the Tanacross quadrangle and from similar 
Figure 2.-Potassium-argon ages, Tanacross and southern Eagle quadrangles, Alaska

[Ages were determined using standard isotope dilution techniques for extraction and measurement of argon and flame photometry for potassium (Dalrymple and Lanphere, 1969). For the new dates, the plus-or-minus value assigned to each is an estimate of the standard deviation of analytical precision (Cox and Dalrymple, 1967), together with an estimate of accuracy based on evaluation of the uncertainties in concentration of the ${ }^{38} \mathrm{Ar}$ tracer and potassium measurements. Where analytical data and the plus-or-minus value for an age are missing, they were not reported by the original author.]

\begin{tabular}{|c|c|c|c|c|c|c|c|c|}
\hline Sample No. & Dated by- & $\begin{array}{l}\text { Location } \\
\text { quadrangle } \\
\text { and latitude } \\
\text { longitude }\end{array}$ & Rock type & $\begin{array}{c}\text { Mineral } \\
\text { dated }\end{array}$ & $\begin{array}{c}\text { Percent } \\
\mathrm{K}_{2} \mathrm{O}\end{array}$ & $\begin{array}{c}{ }^{40} \mathrm{Ar}_{\mathrm{rad}} \\
\left(\begin{array}{c}\mathrm{moles} / \mathrm{gm} \\
\left.\times 10^{-10}\right)\end{array}\right.\end{array}$ & ${ }_{\text {(percent) }}^{{ }^{40} \mathrm{Ar}}$ & $\begin{array}{l}\text { Age in } \\
\text { million years } \\
\text { plus or minus } \\
\text { analytical } \\
\text { uncertainty }\end{array}$ \\
\hline
\end{tabular}

Igneous rocks

\begin{tabular}{|c|c|c|c|c|c|c|c|c|}
\hline 1. $63 \mathrm{AFr} 2 \mathrm{C}$ & $\begin{array}{l}\text { J. Von Essen, } \\
1972 .\end{array}$ & $\begin{array}{l}\text { Eagle A-4; } \\
64^{\circ} 11^{\prime} \mathrm{N} \\
143^{\circ} 00^{\prime} \mathrm{W}\end{array}$ & $\begin{array}{l}\text { Syenite. } \\
\text { porphyry. }\end{array}$ & Hornblende & $1.465,1.477$ & 4.035 & 95 & $177 \pm 5$ \\
\hline 2. $61 \mathrm{AE} 184$ & $\begin{array}{l}\text { Wasserburg } \\
\text { and others, } \\
1963.1\end{array}$ & $\begin{array}{l}\text { Eagle A-3; } \\
64^{\circ} 01^{\prime} \mathrm{N} \\
142^{\circ} 05^{\prime} \mathrm{W}\end{array}$ & Adamellite & Biotite & -n & $\ldots$ & -....... & 180 \\
\hline 3. $74 \mathrm{ASj} 113$ & $\begin{array}{l}\text { J. G. Smith, } \\
1975 .^{2}\end{array}$ & $\begin{array}{l}\text { Tanacross D-3; } \\
63^{\circ} 59^{\prime} \mathrm{N} \\
142^{\circ} 09^{\prime} \mathrm{W}\end{array}$ & Granodiorite & Hornblende & $\begin{array}{l}8.00,7.99 \\
1.011,1.002\end{array}$ & $\begin{array}{c}24.10 \\
2.989\end{array}$ & $\begin{array}{l}93 \\
86\end{array}$ & $\begin{array}{l}194 \pm 5 \\
191 \pm 5\end{array}$ \\
\hline 4. $74 \mathrm{ASj} 105$ & $\begin{array}{l}\text { J. G. Smith, } \\
1976 .{ }^{2}\end{array}$ & $\begin{array}{l}\text { Tanacross D-2; } \\
63^{\circ} 49^{\prime} \mathrm{N} \\
141^{\circ} 41^{\prime} \mathrm{W}\end{array}$ & $\begin{array}{l}\text { Andesite } \\
\text { plug. }\end{array}$ & $\begin{array}{l}\text { Biotite } \\
\text { Hornblende }\end{array}$ & $\begin{array}{l}7.38,7.50 \\
1.138,1.160\end{array}$ & $\begin{array}{l}7.2091 \\
1.1647\end{array}$ & $\begin{array}{l}80 \\
54\end{array}$ & $\begin{array}{l}64.5 \pm 3 \\
67.4 \pm 3\end{array}$ \\
\hline 5. $74 \mathrm{ASj} 143$ & $\begin{array}{l}\text { J. G. Smith, } \\
1976 .^{2}\end{array}$ & $\begin{array}{l}\text { Tanacross } \mathrm{C}-3 \text {; } \\
63^{\circ} 44^{\prime} \mathrm{N} \\
145^{\circ} 01^{\prime} \mathrm{W}\end{array}$ & Welded tuff & Sanidine -- & $12.43,12.54$ & $\begin{array}{l}17.29 \\
17.23\end{array}$ & $\begin{array}{l}92 \\
87\end{array}$ & $\begin{array}{l}91.6 \pm 3 \\
91.2 \pm 3\end{array}$ \\
\hline 6. $61 \mathrm{AE} 186$ & $\begin{array}{l}\text { Wasserburg } \\
\text { and others, } \\
1963 .{ }^{1}\end{array}$ & $\begin{array}{l}\text { Tanacross } \mathrm{C}-3 \text {; } \\
63^{\circ} 40^{\prime} \mathrm{N} \\
142^{\circ} 15^{\prime} \mathrm{W}\end{array}$ & $\begin{array}{l}\text { Alkali } \\
\text { syenite. }\end{array}$ & & & & & 66 \\
\hline 7. $74 \mathrm{ASj} 144$ & $\begin{array}{l}\text { J. G. Smith, } \\
1976 .{ }^{2}\end{array}$ & $\begin{array}{l}\text { Tanacross } \mathrm{C}-3 \\
63^{\circ} 39^{\prime} \mathrm{N} \\
142^{\circ} 15^{\prime} \mathrm{W}\end{array}$ & $\begin{array}{l}\text { Quartz } \\
\text { monzonite. }\end{array}$ & $\begin{array}{l}\text { Biotite } \\
\text { Amphibole }\end{array}$ & $\begin{array}{l}8.64,8.64 \\
0.510,0.496\end{array}$ & $\begin{array}{l}8.513 \\
4.378\end{array}$ & $\begin{array}{l}81 \\
53\end{array}$ & $\begin{array}{l}65.5 \pm 2 \\
58 \pm 3\end{array}$ \\
\hline $\begin{array}{l}\text { 8. } 74 \mathrm{ASj} 110 \\
\text { (74AFr363) }\end{array}$ & $\begin{array}{l}\text { J. G. Smith, } \\
1976 .^{2}\end{array}$ & $\begin{array}{l}\text { Tanacross C-1; } \\
63^{\circ} 37^{\prime} \mathrm{N} \\
141^{\circ} 10^{\prime} \mathrm{W}\end{array}$ & $\begin{array}{l}\text { Biotite } \\
\text { quartz } \\
\text { monzonite. }\end{array}$ & Biotite .... & $8.60,8.60$ & 13.72 & 91 & $105 \pm 3$ \\
\hline $\begin{array}{l}\text { 9. 74ASj111 } \\
\text { (74AFr364) }\end{array}$ & $\begin{array}{l}\text { J. G. Smith, } \\
1976 .^{2}\end{array}$ & $\begin{array}{l}\text { Tanacross B-1; } \\
63^{\circ} 29^{\prime} \mathrm{N} \\
141^{\circ} 08^{\prime} \mathrm{W}\end{array}$ & Welded tuff & Sanidine & $8.54 ; 8.64$ & 7.263 & 67 & $56.4 \pm 2$ \\
\hline 10. $74 \mathrm{ASj} 140$ & $\begin{array}{l}\text { J. G. Smith, } \\
1976 .^{2}\end{array}$ & $\begin{array}{l}\text { Tanacross B-6; } \\
63^{\circ} 24^{\prime} \mathrm{N} \\
143^{\circ} 55^{\prime} \mathrm{W}\end{array}$ & $\begin{array}{l}\text { Olivine } \\
\text { gabbro. }\end{array}$ & Blotite & $9.09,9.06$ & 8.859 & 74 & $65.0 \pm 2$ \\
\hline $\begin{array}{l}\text { 11. H. Foster } 3 \\
(72128)\end{array}$ & $\begin{array}{l}\text { D. L. Turner, } \\
1975 .^{3}\end{array}$ & $\begin{array}{l}\text { Tanacross B- } 4 \text {; } \\
63^{\circ} 20^{\prime} \mathrm{N} \\
142^{\circ} 36^{\prime} \mathrm{W}\end{array}$ & Gabbro & Hornblende $\ldots . . . .$. & $0.552,0.555$ & 1.121 & 87.6 & $132.6 \pm 4$ \\
\hline 12. $74 \mathrm{ASj} 139$ & $\begin{array}{l}\text { J. G. Smith, } \\
1975.2\end{array}$ & $\begin{array}{l}\text { Tanacross B-6; } \\
63^{\circ} 19^{\prime} \mathrm{N} \\
143^{\circ} 30^{\prime} \mathrm{W}\end{array}$ & $\begin{array}{l}\text { Biotite } \\
\text { quartz } \\
\text { monzonite. }\end{array}$ & Biotite do & $\begin{array}{l}7.85,7.88 \\
7.94,7.94 \\
8.00\end{array}$ & 10.48 & 94 & $87.6 \pm 3$ \\
\hline 13. $74 \mathrm{ASj} 114$ & $\begin{array}{l}\text { J. G. Smith, } \\
1975 .^{2}\end{array}$ & $\begin{array}{l}\text { Tanacross A-3; } \\
63^{\circ} 10^{\prime} \mathrm{N} \\
142^{\circ} 06^{\prime} \mathrm{W}\end{array}$ & _.... do _......... & do do & $\begin{array}{l}803,8.04 \\
8.05,8.19 \\
8.20,8.26\end{array}$ & 11.70 & 92 & $95.0 \pm 3$ \\
\hline 14. $74 \mathrm{AFr} 926$ & $\begin{array}{l}\text { J. G. Smith, } \\
\text { 1976.2 }^{2}\end{array}$ & $\begin{array}{l}\text { Tanacross C-1; } \\
63^{\circ} 39^{\prime} \mathrm{N} \\
141^{\circ} 18^{\prime} \mathrm{W}\end{array}$ & $\begin{array}{r}\text { Hypabyssal } \\
\text { intrusive. }\end{array}$ & - & $9.02,8.95$ & 8.656 & 86 & $64.1 \pm 2$ \\
\hline
\end{tabular}

Metamorphic rocks

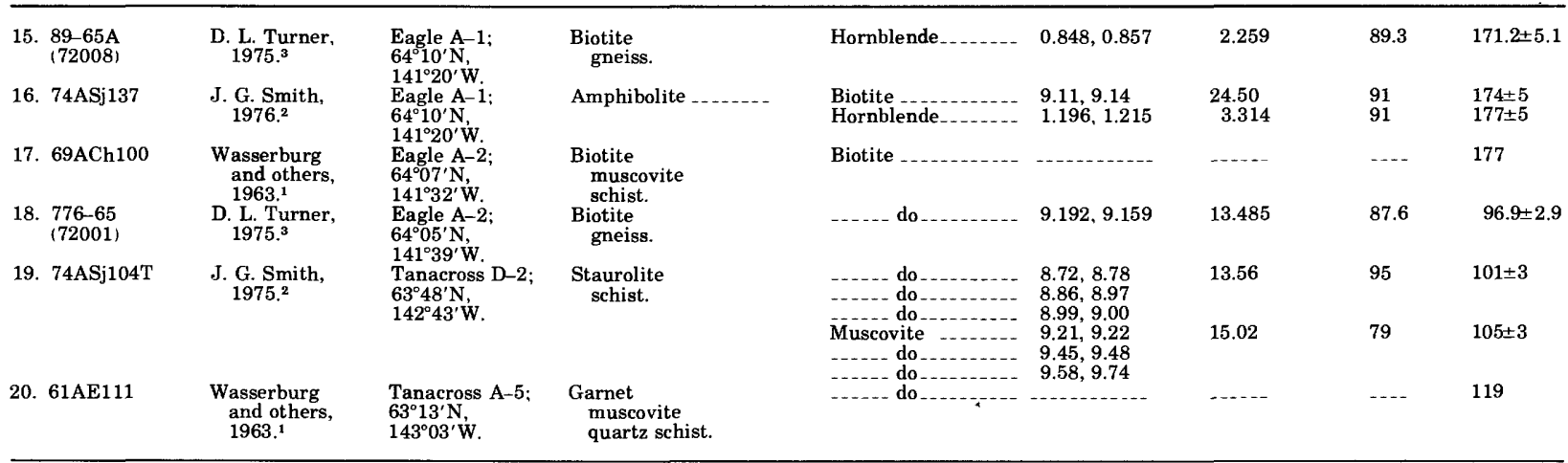

${ }^{1}$ Wasserburg, C. J., Eberlein, G. D., and Lanphere, M. A., 1963.

2Smith, J. G., unpub, data, 1975.

3:Turner, D. L., oral commun., 1975.

rock units in the southern Eagle quadrangle (fig. 3, table 2).

The potassium-argon ages reveal a long history of metamorphism, intrusion, and volcanism. The available data suggest three periods of intrusion,

the younger two of which coincide with eruptive volcanic activity. Most of the mineralization in the quadrangle is associated with the youngest period of intrusion.

The oldest intrusive event was the Early Juras- 
sic (approximately 175-195 m.y. ago) emplacement of the Taylor Mountain batholith and syenite of Mount Veta. These plutons intruded a previously regionally metamorphosed biotite gneiss and schist terrane; xenoliths of gneiss are present in the Taylor Mountain batholith. Regionally this intrusive event is roughly equivalent in age to that of a diorite complex south of the Denali fault in the adjacent Nabesna quadrangle (Richter and others, 1975).

The next younger plutonic event took place in middle Cretaceous time (85-105 m.y. ago) and is not well established in the Tanacross quadrangle. The reasons for this uncertainty are that only a few plutons of middle Cretaceous age have been dated, the ages are scattered, and the outcrops sampled lack hornblende; thus ages based on coexisting mineral pairs could not be obtained. The plutons typically are coarse-grained porphyritic biotite quartz monzonite, locally poor in mafic minerals. In texture and petrography, they resemble the Gardiner Creek and Tok-Tetlin plutons in the adjacent Nabesna quadrangle (Richter and others, 1975) and the Coffee Creek Quartz Monzonite in the Yukon Territory (TemplemanKluit and Wanless, 1975). Plutons of similar age, composition, and petrography have been dated by Frederic H. Wilson (oral commun., 1975) from the adjacent Mount Hayes and Big Delta quadrangles. An age of $91 \mathrm{~m}$.y. on sanidine from a welded tuff from near Mount Fairplay indicates that at least some of the plutons vented to the surface. The distribution of plutons of similar age and composition over more than $103,600 \mathrm{~km}^{2}(40,000$ $\mathrm{mi}^{2}$ ) indicates a major period of plutonic activity in this part of Alaska and adjacent Yukon Territory during middle Cretaceous time.

The youngest plutonic event was marked by intrusion of generally small isolated plutons, including hypabyssal stocks, and by the eruption of silicic and mafic volcanic rocks during the Paleocene (55-65 m.y. ago). The Mount Fairplay pluton and the hypabyssal stock associated with a copper prospect near McCord Creek were intruded at this time. Most of the volcanic rocks outside of the Mount Fairplay area were probably also erupted in the Paleocene. Preliminary data suggest that much of the hydrothermal alteration in McCord Creek and other areas that contain the altered felsic volcanic rocks took place at this same time.

The potassium-argon data on the metamorphic rocks are more difficult to interpret than those on the igneous rocks. Most of the metamorphic rock samples were dated in an attempt to determine the pre-Mesozoic history of the Yukon-Tanana Upland. However, the ages show that the potassium-argon technique is unable to penetrate beyond the Mesozoic metamorphic events. Most of the Mesozoic ages on the metamorphic rocks probably reflect older ages that have been partly or completely reset by younger thermal events.

\section{DESCRIPTION OF COMPONENT MAPS OF THE TANACROSS QUADRANGLE FOLIO}

GEOLOGY (MAP I-593)

A multicolor geologic map of the Tanacross quadrangle was published by Foster (1970). The fieldwork for this map was of a highly reconnaissance nature, and geochemical and geophysical data were not available at the time of compilation.

In the summer of 1974 under AMRAP, some additional traverses and geologic observations were made in parts of the Tanacross quadrangle, but the amount of new work is not sufficient to justify the publication of a revised geologic map. However, some revisions resulting from the summer's fieldwork appear on a series of maps in this circular (figs. 4-13), each map showing a part of the Tanacross quadrangle. Some areas, such as the Tanacross A-1, A-2, A-3, and A-4 1:63, 360scale quadrangles, are not included, because no new fieldwork was done there.

Much of the quadrangle still has not been covered by "on the ground" observations and traverses. Additional geologic fieldwork would result in many more additions and changes to the geologic map. For example, contacts between granitic and metamorphic rocks cannot be detected from the air or from aerial photographs and can only be determined with confidence when ground observations are available. Many contacts are actually contact zones with a considerable admixture of several kinds of rock.

No change in the number or names of map units is attempted here, but additional information is given on the felsic and mafic volcanic rocks and the syenite of Mount Fairplay.

\section{FELSIC VOLCANIC ROCKS}

The felsic volcanic rock unit includes in some localities shallow felsic intrusive rocks, many of 


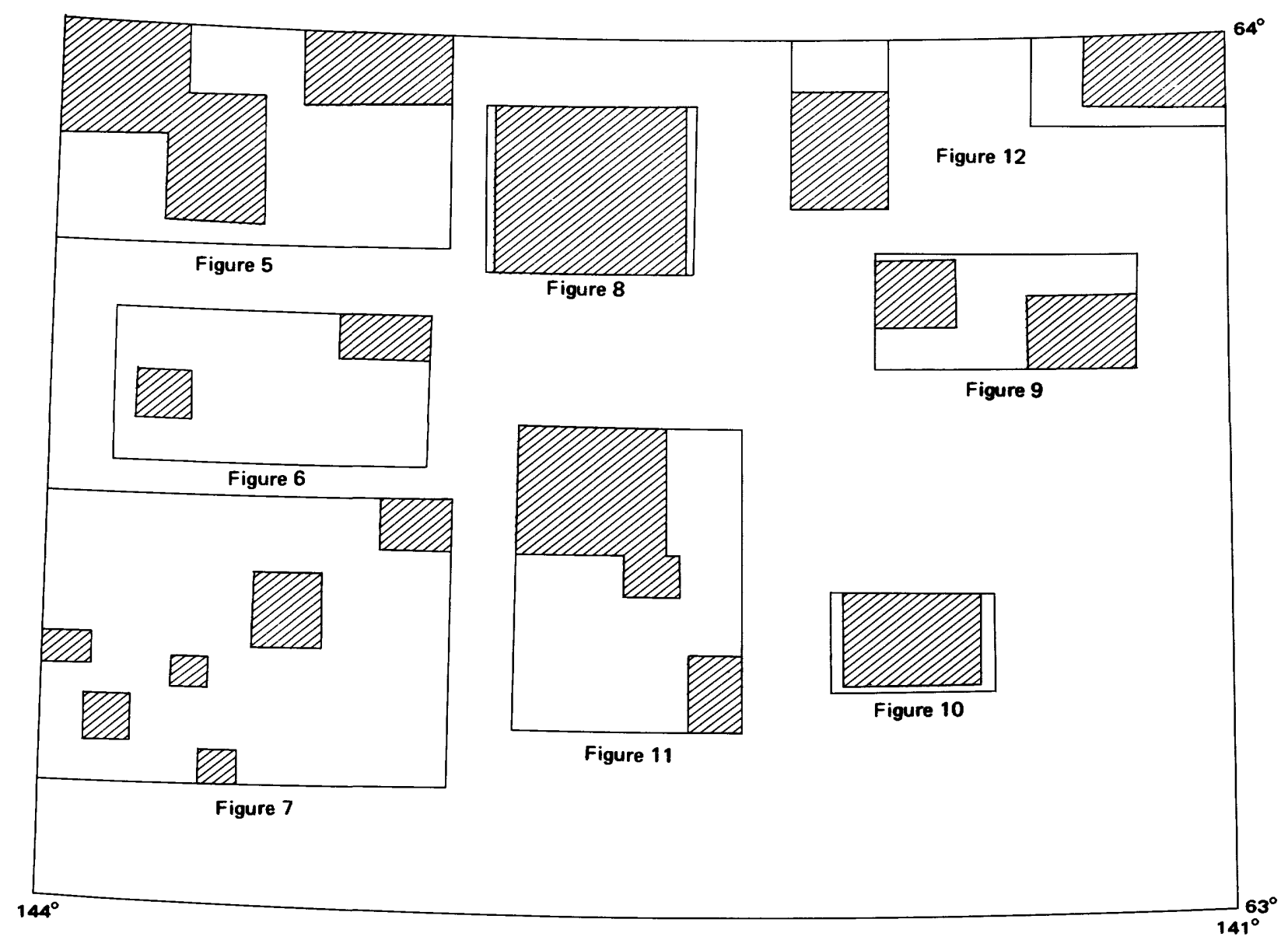

FIGURE 4.-Localities where revisions are made to the Reconnaissance Geologic Map of the Tanacross quadrangle, Alaska (Foster, 1970). Diagonal lines indicate areas with revisions.

which are porphyritic and hydrothermally altered. The principal occurrences of such hydrothermally altered intrusive rocks are in the headwaters of McCord Creek in the $\mathrm{C}-1$ quadrangle, $3.2 \mathrm{~km}(2 \mathrm{mi})$ southwest of the bench mark "Dennis" in the B-4 quadrangle, southeast of the bench mark "Mosquito" in D-5 and D-6 quadrangles, and locally near Mount Fairplay in the $\mathrm{C}-5$ quadrangle.

Some of the intrusive rocks included in this unit are similar to those included in the granite porphyry, except that most of the former are more altered.

Rocks mapped as felsic volcanic rocks (Foster, 1970) near McCord Creek include quartz latite, felsic tuff(?), quartz-feldspar and quartz-tourmaline rock, and porphyrytic hypabyssal rocks ranging in composition from quartz diorite to granite.
Some are felsic breccias. Quartz monzonite and granodiorite are mapped adjacent to this unit and, where highly altered, may be included in it. The rocks locally are much silicified, and sericite and clay minerals are abundant. Quartz phenocrysts commonly are embayed, and the feldspar phenocrysts strongly zoned. Felsic intrusive rocks probably cover a larger area than shown on the map in the McCord Creek area.

Rocks mapped as felsic volcanic rocks in the B-4 quadrangle (Foster, 1970) are mostly altered granitic porphyry with abundant highly strained quartz, zoned plagioclase, and microcline phenocrysts. Some rocks also have biotite and hornblende phenocrysts. Exsolution features and intergrowth are common in the feldspars of some rocks. Hydrothermal alteration is indicated by abundant epidote, chlorite, clay minerals, and 


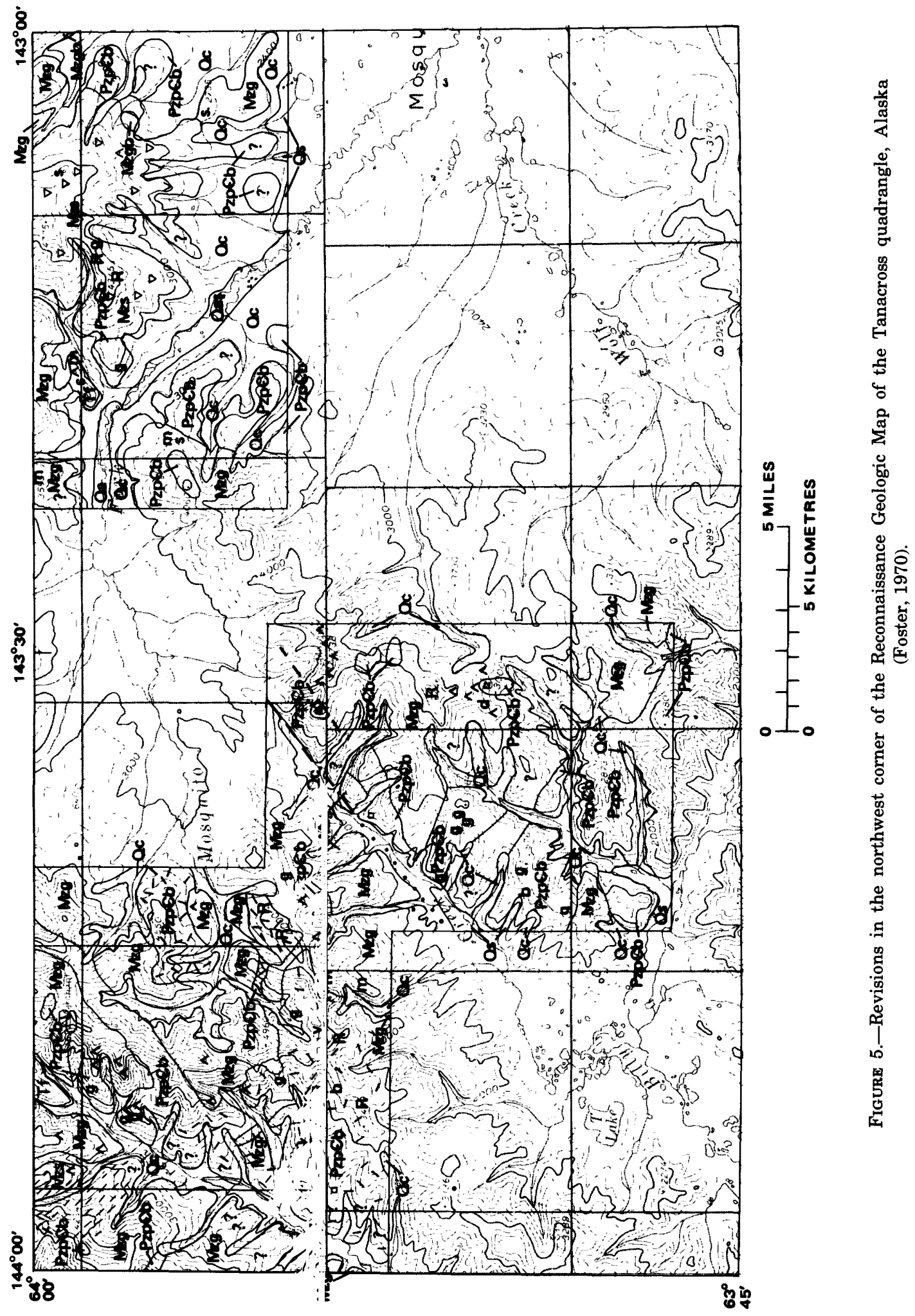




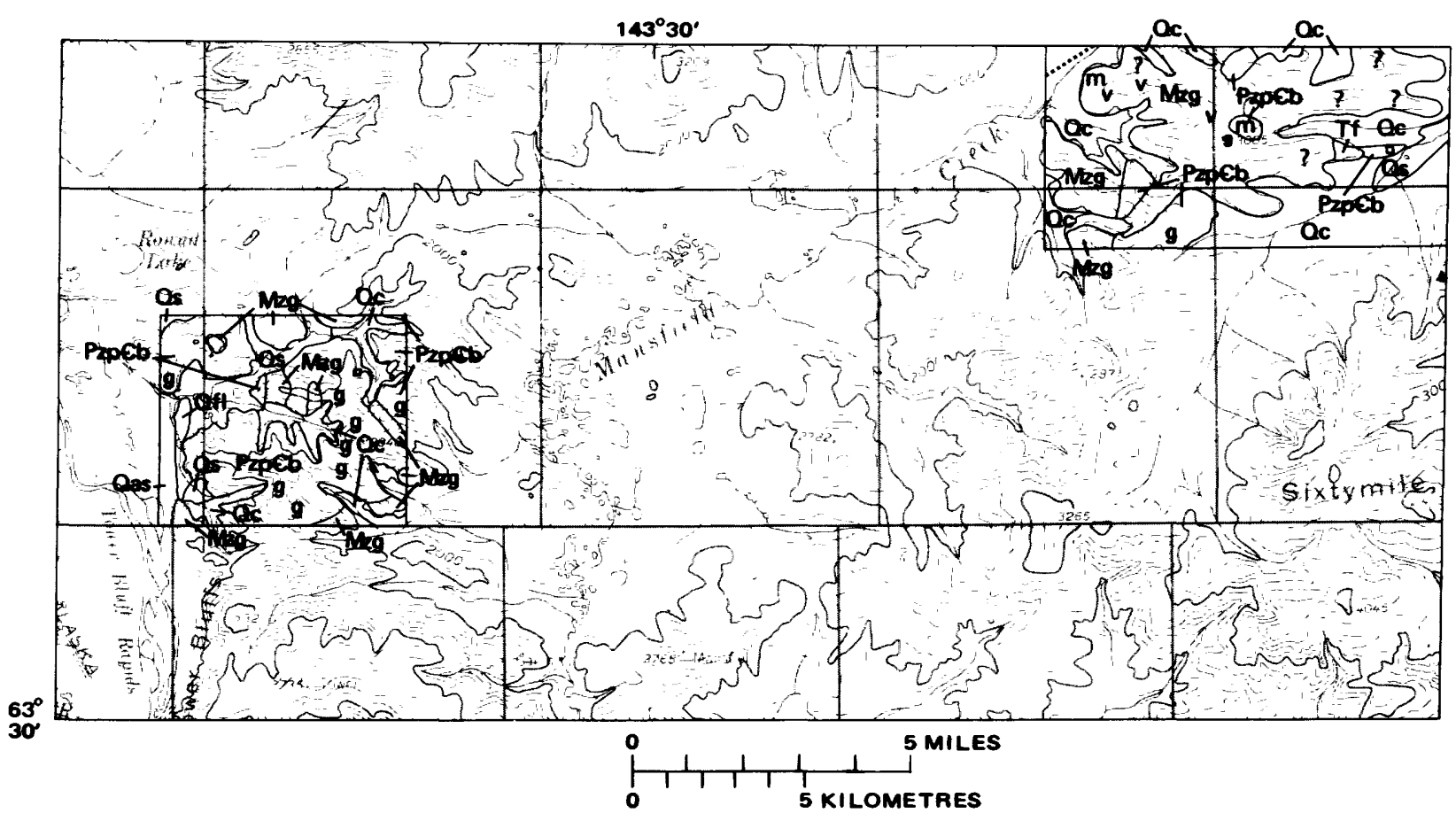

Figure 6.-Revisions in the west-central part of the Reconnaissance Geologic Map of the Tanacross quadrangle, Alaska (Foster, 1970).

sericite, and locally the rocks are silicified to various extents. Cataclasis is evident in different degrees in most of the rocks.

Original rock types are difficult to determine because of the extensive alteration, but they may include lava as well as hypabyssal intrusive rocks. Tuff has not been definitely identified but may be present.

Felsic volcanic rocks in the "Mosquito" area (Foster, 1970) occur mostly as small, isolated patches but in a few places cover an area of hundreds of square metres. They are more extensive in this area than indicated by the geologic map. These rocks are in contact with granitic and metamorphic rocks, but most contacts are obscure and are indicated by patches of rubble of mixed rock types. The most abundant rock type included in the unit in this area is porphyrytic with a fine- to medium-grained groundmass. Phenocrysts are euhedral and subhedral quartz, some of which is mildly strained, altered feldspar (both plagioclase and potassium feldspar), biotite, and hornblende. The rocks range from slightly altered to so completely altered that their original texture and composition cannot be determined. Sericite, clay minerals, and quartz, and chlorite are the most abundant alteration products, but limonite, carbonate, and other minerals also occur.

Tuff has not been definitely identified, although spherulites and other textural features in some rocks indicate that they are extrusive.

Examples of large areas where the unit is composed dominantly of felsic volcanic rocks are Sixtymile Butte and the vicinity of Mount Fairplay (Foster, 1970). Sixtymile Butte is a thick pile of devitrified and altered welded tuff. The unit around Fairplay is composed of several kinds of altered tuff, lava, and breccia, including abundant altered welded tuff. A minor amount of shallow intrusive rock, mostly somewhat altered, is also included in the unit near Mount Fairplay.

From potassium-argon ages recently determined, it appears that rocks included in the felsic volcanic rock unit may be of several ages. For example, a single age on tuff (fig. 3; table 2, No. 5) north of Mount Fairplay is about 91 m.y., whereas welded tuff near the east margin of the quadrangle is about 56 m.y. (fig. 3; table 2, No. 10). However, alteration and mineralization of the volcanic and intrusive rocks in the unit may have been a single event corresponding to one of the Tertiary ages.

\section{MAFIC VOLCANIC ROCKS}

The mafic volcanic rocks at the head of Big Creek (Foster, 1970) include both mafic lava and volcanic sediments. One or more small plugs, dikes, or sills and flows are in contact with vol- 


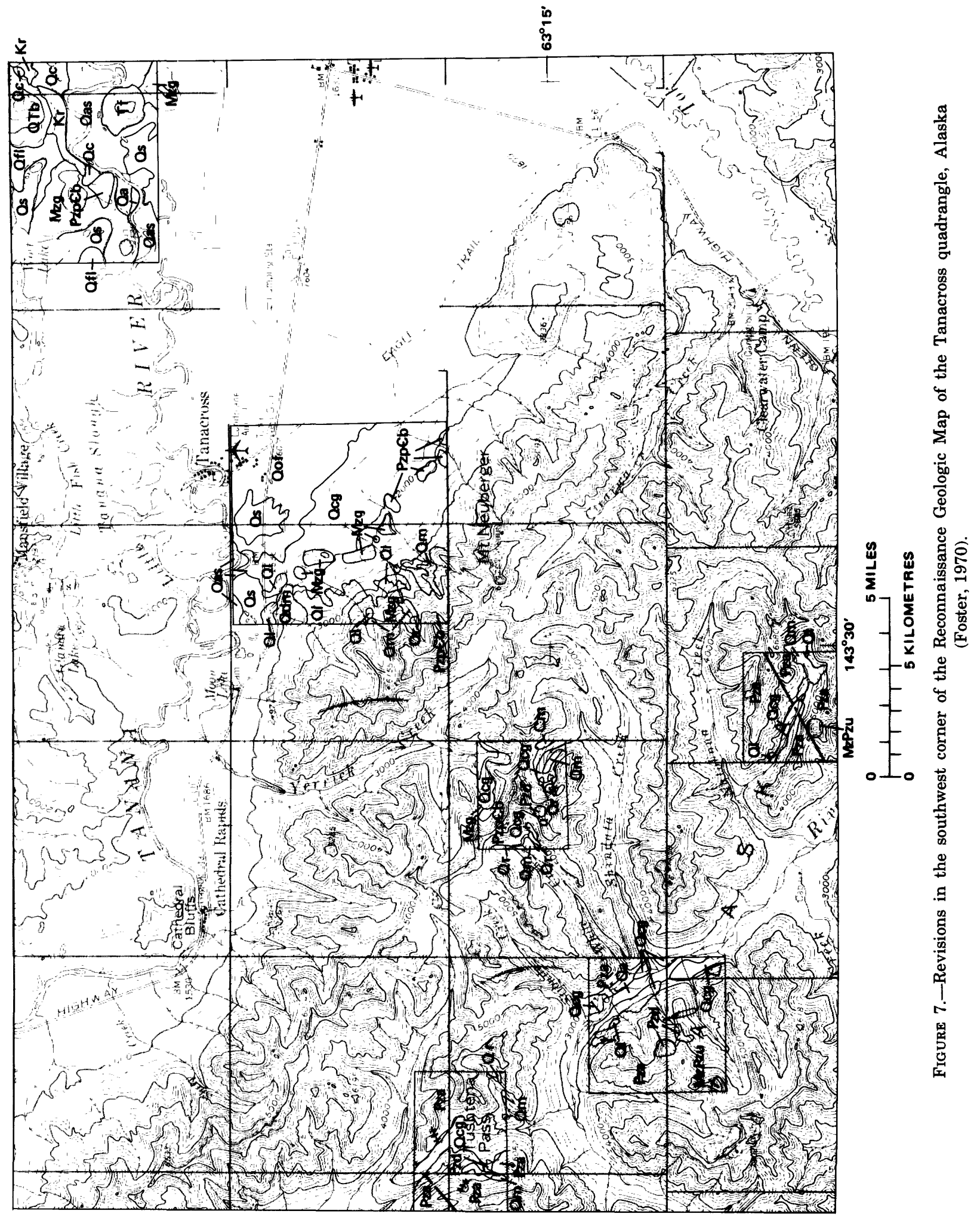




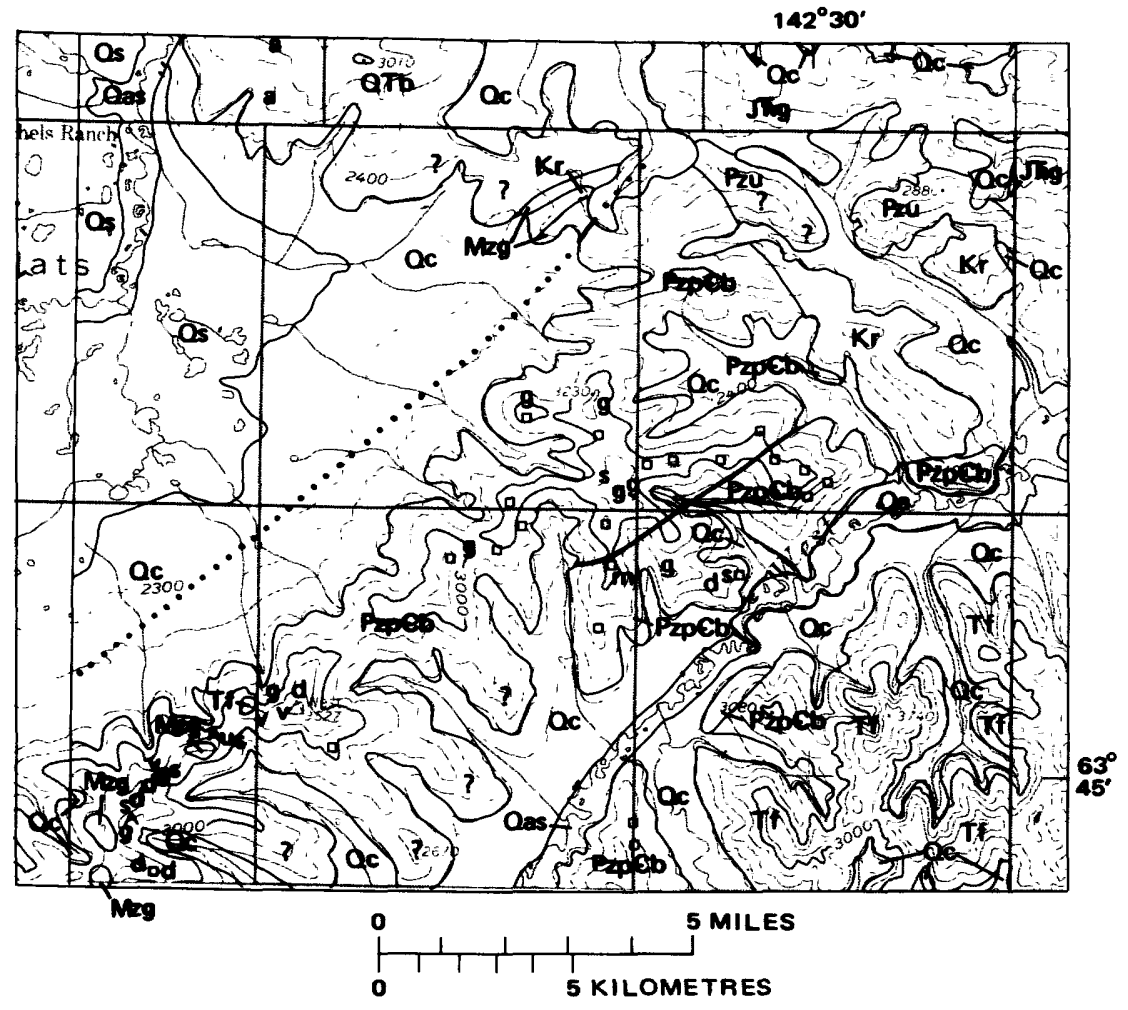

FiguRE 8.-Revisions in the north-central part of the Reconnaissance Geologic Map of the Tanacross quadrangle, Alaska (Foster, 1970).

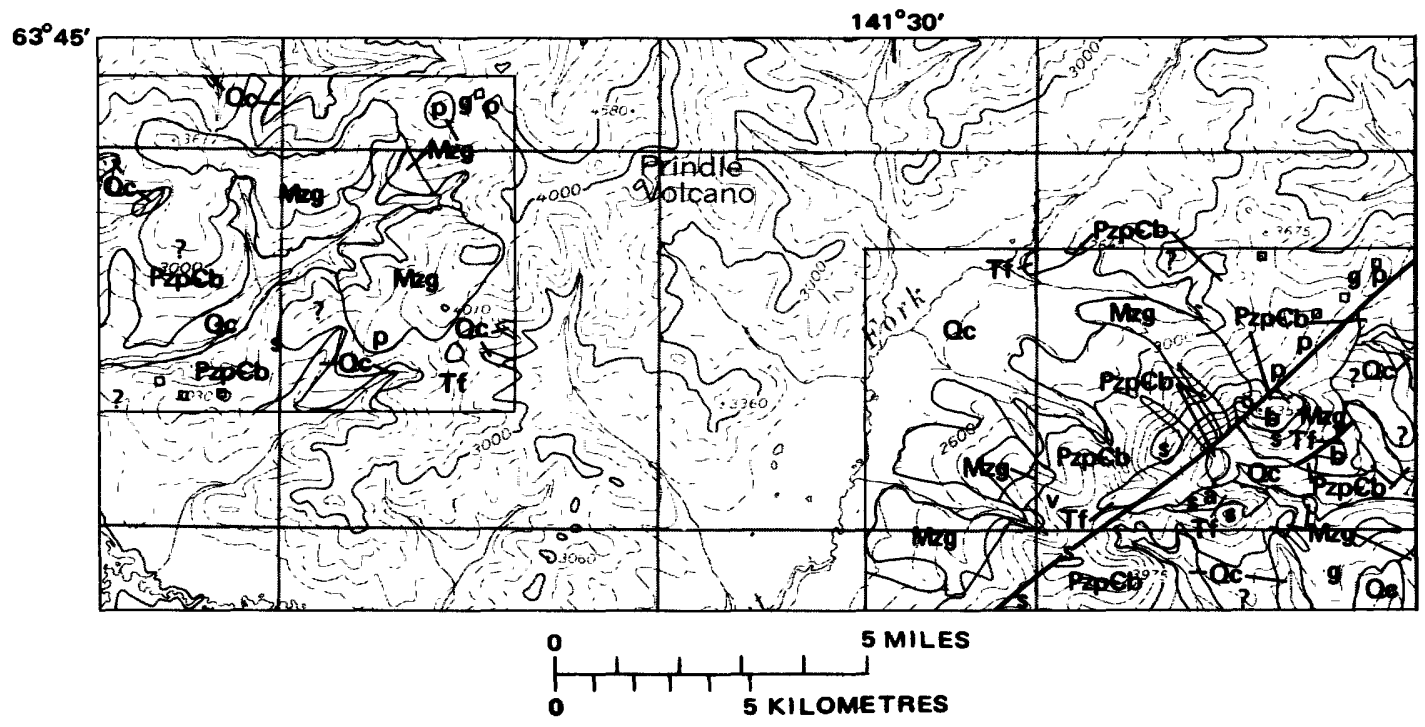

FIgURE 9.-Revisions in the east-central part of the Reconnaissance Geologic Map of the Tanacross quadrangle, Alaska (Foster, 1970). 


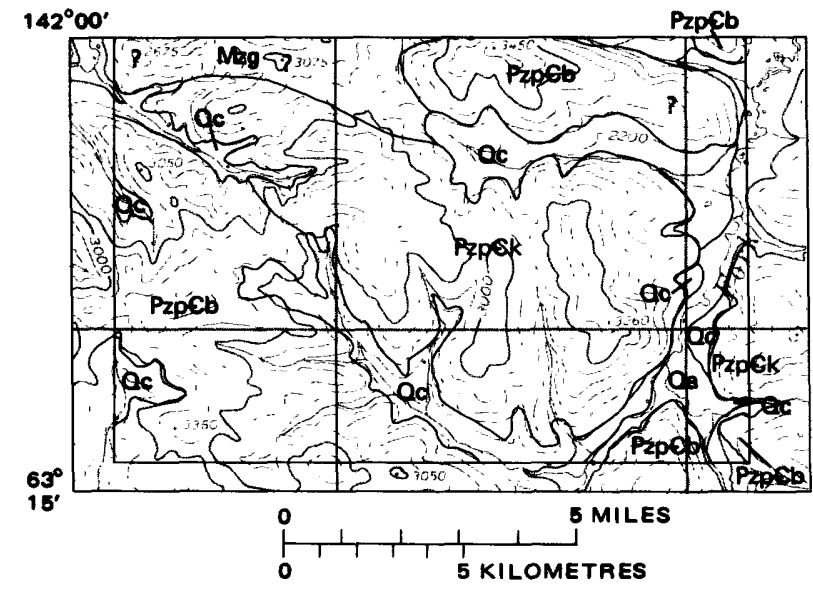

Figure 10.-Revisions in the southeastern part of the Reconnaissance Geologic Map of the Tanacross quadrangle, Alaska (Foster, 1970).

canic conglomerates and other volcanic sediments. Bedding has a northerly dip and northeasterly strike, although there are local variations. The volcanic sediments are well indurated and locally show baking along contacts with sills or flows. Elsewhere contact effects are not evident.

\section{SYENITE OF MOUNT FAIRPLAY}

The syenite of Mount Fairplay includes granodiorite in addition to the other rocks mentioned in the description of the unit (Foster, 1970). Syenite may not be the dominant rock, and the coarsely porphyrytic type of syenite occurs only locally, mostly in the west-central part of the intrusion.

\section{GEOPHYSICS}

\section{AEROMAGNETIC MAP AND INTERPRETATION} (MAPS MF 767A, 2 SHEETS)

The aeromagnetic map (sheet 1) of the Tanacross quadrangle was flown in 1971 and subsequently released by the State of Alaska as an open-file map (Alaska Division of Geological and Geophysical Surveys, 1973). The variations in the magnetic field on maps such as these provide valuable information concerning the lateral and vertical extent of rocks containing various percentages of magnetic minerals, usually magnetite. Aeromagnetic maps thus are a most useful support for a geologic mapping program as well as for mineral resource assessment. An interpretive map (sheet 2) identifies several kinds of rocks in the Tanacross quadrangle that possess characteristic magnetic anomalies and enables the interpreter to extrapolate geologic information from known areas into covered or inaccessible regions. In addition, the interpretive map portrays faults on the basis of linear interruptions in the magnetic patterns. By using the magnetic interpretation together with geologic information, certain areas are defined that may be favorable for gold or porphyry copper mineralization.

\section{GRAVITY MAP (MAP MF-767B)}

The gravity map provides a plot of nearly 150 gravity measurements that have been made in the quadrangle and shows some 10-milligal contouring that was initially drawn for a regional compilation of the entire State. All of the measurements were made between 1959 and 1963, during the early stages of the State reconnaissance, and have been supplemented only by later base-station checks. Eighty percent of the measurements were made along the highway network; the remaining stations were reached by floatplane and helicopter.

The limited available data suggest that there are few large gravitational anomalies within the Tanacross quadrangle. The maximum range of gravity within the quadrangle is less than 50 milligals, most of which can probably be explained by a thinning of the crust below the low topography in the Northway-Tanacross Lowland relative to the thicker crust beneath the higher mountains of the Alaska Range and Yukon-Tanana Upland. The data also suggest that some of the plutons have gravitational expression and that detailed surveys might help to define the shape, size, and possibly the mode of emplacement of these bodies. Small gravity anomalies are also associated with low-density sediments underlying the flatter parts of the Tok, Tanana, and Mosquito-Fork River valleys.

\section{INTERPRETATION OF LANDSAT IMAGERY (MAP MF-767C, 3 SHEETS)}

Interpretation of Landsat data of the Tanacross quadrangle is based on (1) a black and white Landsat photomosaic of the State of Alaska compiled by the U.S. Department of Agriculture and (2) computer-enhanced black and white and color Landsat imagery processed by the U.S. Geological Survey in Flagstaff, Ariz., and by the Jet Propulsion Laboratory in Pasadena, Calif. 


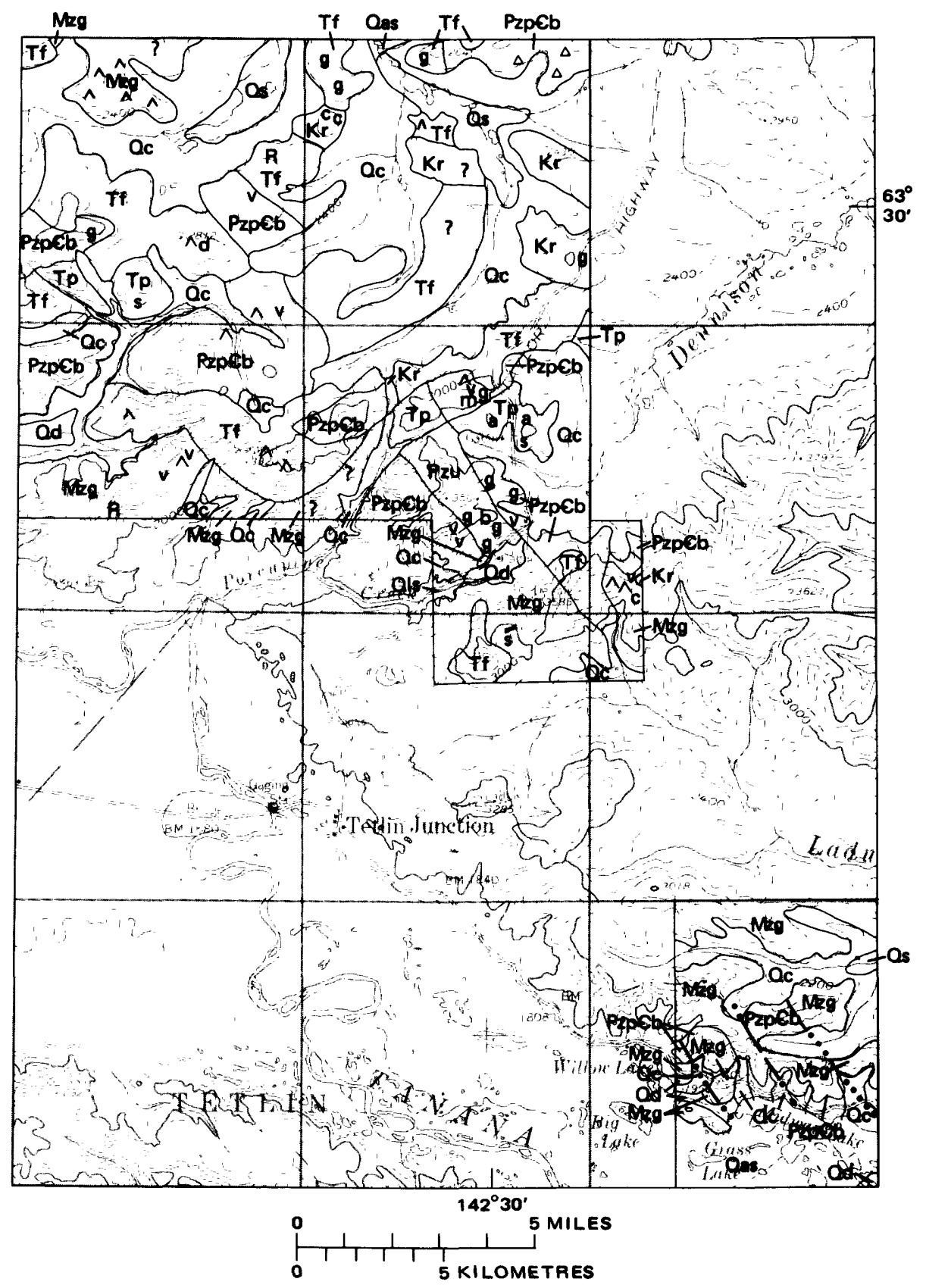

FIGURE 11.-Revisions in the south-central part of the Reconnaissance Geologic Map of the Tanacross quadrangle, Alaska (Foster, 1970).

As a geologic mapping tool, Landsat imagery is probably most effective for reconnaissance studies. Remotely sensed information about geomorphology, structural features, and variations in spectral response of surficial materials, for example, have use in planning and directing geologic mapping and geochemical sampling. However, in areas such as the Tanacross quad- rangle, where reconnaissance geologic mapping and geochemical sampling were completed prior to the availability of Landsat data, the Landsat imagery can be used to augment geologic and geophysical concepts by identifying possible fault extensions, identifying linear features not discernible in the field, analyzing joint and smallscale fracture patterns, and identifying structural 

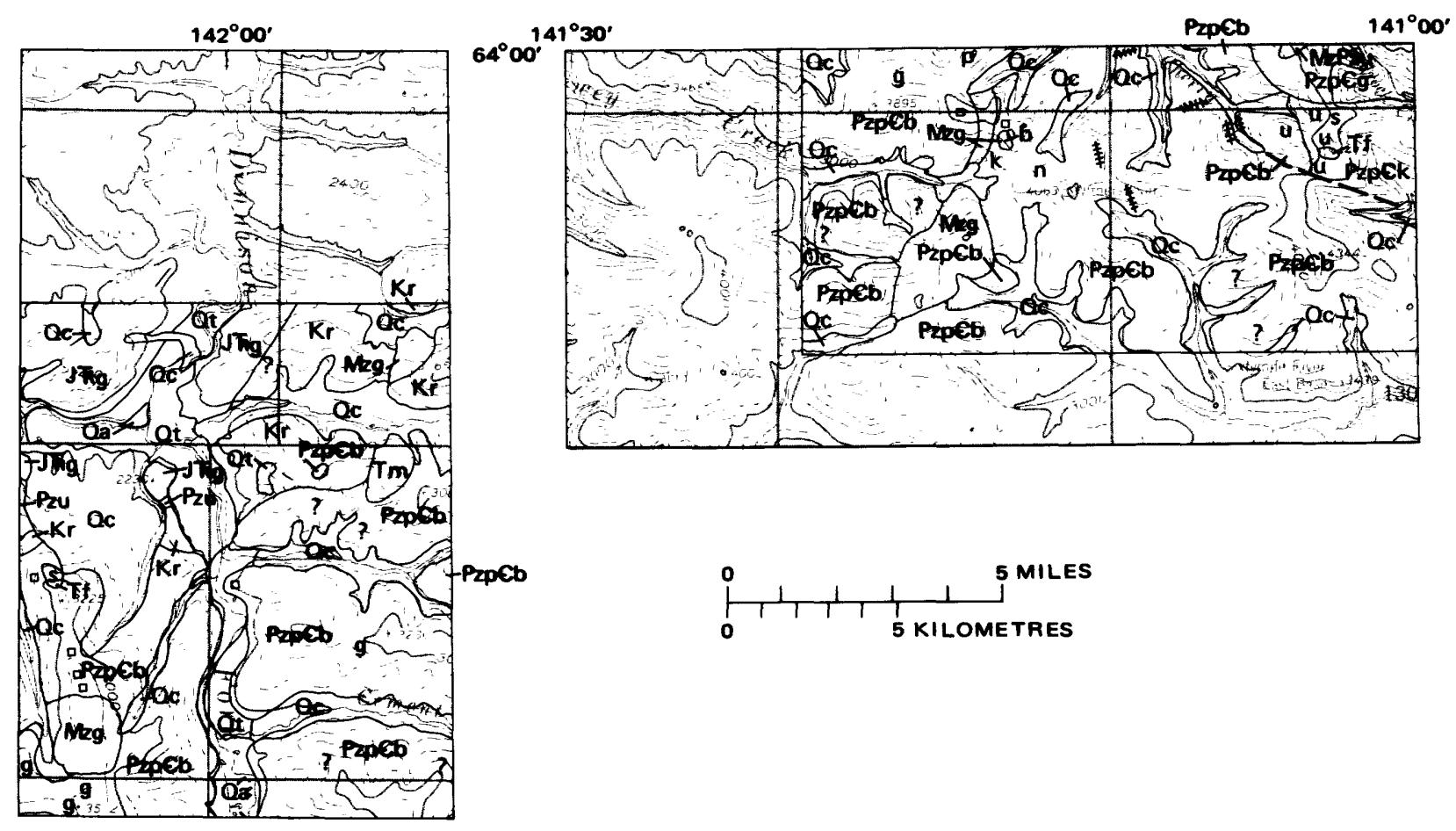

FIGURE 12.-Revisions in the northeastern corner of the Reconnaissance Geologic Map of the Tanacross quadrangle, Alaska (Foster, 1970).

features and relations that might have significance for mineral exploration.

Because most of the Tanacross quadrangle has a heavy cover of vegetation, variations in spectral responses for rock and soil types are difficult to assess. In addition, vegetation stresses (extraordinary changes in growth characteristics) possibly caused by anomalous concentrations of minerals are difficult to distinguish on the Landsat imagery from variations in vegetation caused by the numerous forest fire scars.

Direct applications of Landsat imagery to mineral resource assessment are still developing. As a result, interpretation techniques used in the Tanacross quadrangle are mostly experimental.

\section{LAND STATUS (MAP MF-767D)}

The land status map shows the classifications and boundaries of proposed and existing categories of land in the Tanacross quadrangle as of about December 1975. The map was compiled from a much smaller scale map prepared in March 1974 by the U.S. Bureau of Land Management. Although changes have now occurred primarily because of land selections made under terms of the Alaska Native Claims Settlement Act (ANCSA) of December 18, 1971, the map is useful as a general guide until new maps can be compiled.

\section{MINERAL RESOURCES (MAP MF-767E)}

An assessment of the occurrence of mineral deposits in the Tanacross quadrangle by area and by deposit type is presented in the mineral resources map. Both known deposits and areas favorable for the occurrence of unfound deposits are delineated. The assessment is limited to the endowment of resources; whether the unfound deposits will at some time be discovered is not considered since that will depend upon the effectiveness and intensity of exploration.

Selection of favorable areas was based on information from the known deposits, combined with geologic, geochemical, geophysical, and earth satellite data presented in other components of the Tanacross folio. A list of the criteria used in the selection of each favorable area is provided with the mineral resources map. It should be noted that without detailed drilling, it is impossible to insure that all favorable areas are shown or that areas selected actually contain deposits; this is particularly true in the Tanacross quadrangle where bedrock exposure is poor. Despite this limitation, the resource assessment should provide useful information for land clas- 


\section{EXPLANATION}

Figures 5 to 12 show areas with revisions to "Reconnaissance geologic map of the Tanacross quadrangle, Alaska", Miscellaneous Geologic Investigations Map I-593 (Foster, 1970). For detailed descriptions of units, refer to Map I-593.

\section{Unconsolidated deposits (Quaternary)}

Os Alluvium, primarily gravel and sand

Qas Alluvium, primarily silt and sand

Os Silt and peat deposits

al Landslide deposits

Ocg Alluvium and colluvium, primarily gravel, sand, and rubble

Oc Alluvium and colluvium, primarily silt and sand

or Rock-glacier deposits

\section{Sedimentary rocks (Cretaceous?)}

$\mathrm{Kr} \quad$ Detrital rocks

Metamorphic rocks

Pza Phyllite and schist unit (Paleozoic?)

Pzu Schist and quartzite unit (Paleozoic?)

Pzpck Quartz-mica schist unit (Precambrian and (or) Paleozoic)

Pzpeg Quartz-graphite schist unit (Precambrian and (or) Paleozoic)

\section{Igneous rocks}

QTb Basalt (Tertiary or Quaternary)

Tm Mafic volcanic rocks (Tertiary?)

Tf Felsic volcanic rocks (Tertiary?)

Tp Granite porphyry (Tertiary?)

JTg Granodiorite of Taylor Mountain batholith (Triassic or Jurassic)

Megb Gabbro and basaltic rocks of Ketchumstuk Mountain (Mesozoic?)

Mrs Hornblende syenite porphry (Mesozoic?)

Each triangle indicates approximate locality where porphyritic syenite rubble was found

Other map symbols

a Augen gneiss

s Abundant sulfides

? Area not visited. Type of rock not definitely known
QfI Fluvial and lacustrine deposits

Qls Lake deposits

Qt Terrace deposits

Om Moraines of the Donnelly Glaciation

ad Eolian deposits, primarily in dunes

Qof Alluvial fan deposits of the Delta Glaciation

Odm Moraines of the Delta Glaciation

Country rock cut by one or more dikes, sills, or other small igneous masses, commonly indicated only by a mixture of rock types in rubble. Letter indicates composition.

$\begin{array}{lll}\text { p. pegmatite } & d, & \text { diorite or quartz diorite } \\ \text { g, granite } & \mathrm{m}, \text { mafic, mostly andesite } \\ \text { k, alaskite } & \mathrm{u}, \text { ultramafic } \\ \text { a, aplite } & \mathrm{n}, \text { greenstone dikes } \\ \mathrm{R}, \text { rhyolite; definite quartz phenocrysts } & ++ \text { marble layers } \\ \text { v, rhyolite or dacite } & \wedge & \text { granite porphyry }\end{array}$

Strike and dip symbols and pingo locations are not shown on revised maps. Refer to Map I-593 for this information.

FIGURE 13.-Explanation for revisions to the Reconnaissance Geologic Map of the Tanacross quadrangle, Alaska (Foster, 1970).

sification and developmental planning by State, about mineral commodities that occur or might industrial, and native interests. Information occur in the quadrangle will be of use in making a 
national minerals policy.

Indications of mineralization are widespread in the quadrangle, but only two types of mineral deposits are presently known: one consists of porphyry copper and molybdenum deposits; the other is an antimony-bearing vein deposit. The porphyry deposits generally are associated with Tertiary felsic volcanic rocks; the vein deposit and probably other vein deposits containing a variety of metals occur in the metamorphic rocks of the Alaska Range and probably less commonly in the metamorphic rocks in other parts of the quadrangle. Although skarn copper and stratiform copper deposits have not been found, these types of deposits are known to exist in similar geologic terrane in Canada and by analogy could occur in the Tanacross quadrangle.

\section{RECONNAISSANCE GEOCHEMISTRY (MAPS MF-767F-0)}

\section{COLLECTION OF SAMPLES}

Reconnaissance geochemical studies were made in the Tanacross quadrangle during the summers of 1967 and 1974 to help determine the mineral resource potential of the quadrangle by defining areas of anomalous metal content. The geochemical data from the 1974 field season are presented and discussed in this folio; the geochemical data from the 1967 fieldwork are presented in other reports (Clark and Foster, 1969; Clark and others, 1969). The geochemical data delineate areas of known mineral occurrences and additional areas possibly containing undiscovered mineral resources. The results also show that scavenging agents, such as materials rich in secondary iron-manganese oxides and decaying organic matter, are the most useful sample media for reconnaissance geochemical studies in the maturely dissected areas of the quadrangle. In the more rugged mountainous areas, detrital materials such as minus-80-mesh stream sediments and heavy-mineral concentrates are the most useful types of samples for reconnaissance geochemical exploration. The results further indicate that areas of anomalous metal content are more completely defined by data from a combination of sample media than by data from any one sample medium.

During the summer of 1974 , geochemical samples were collected at about 600 sites in streams draining areas ranging from 5 to $25 \mathrm{~km}^{2}$ at an average sampling density of one site per $20 \mathrm{~km}^{2}$. Samples were also collected at an additional 35 sites in swampy areas. Comparisons were made of the distribution and abundance of copper, molybdenum, lead, zinc, arsenic, mercury, beryllium, bismuth, tin, and tungsten in five sample media. These media are (1) heavy-mineral concentrates, (2) minus-80-mesh stream sediment, (3) oxide residue (oxalic-acid-leachable fraction) of stream sediment, (4) aquatic bryophytes (mosses), and (5) sureambank sod (mixed organic and inorganic material) collected beneath the water level.

Approximately 864 samples of rocks were also collected and analyzed by semiquantitative emission spectrography for 30 elements, and by atomic absorption for gold. Selected samples were also analyzed by atomic absorption for lead, zinc, and mercury. The results of these analyses were used in the preparation of this folio, and the complete analyses are available in an open-file report (O'Leary and others, 1976).

\section{DESCRIPTION OF SAMPLE MEDIA}

Stream sediments and heavy-mineral concentrates were collected in active channels of streams. The material in samples of stream sediment ranges in size from fine sand and silt in areas of low relief to coarse sand in areas of high relief. The minus-80-mesh stream sediment and the heavy-mineral concentrates represent detrital material that has been mechanically introduced into a stream from bedrock and colluvium within a particular drainage basin. The minus80-mesh sediment may reflect the presence of outcropping mineralized rock upstream. The heavy-mineral concentrates are useful for determining the distribution of certain heavy metals and resistate minerals such as gold, platinum, cassiterite, and scheelite.

The secondary iron and manganese oxides coating stream sediment particles (oxide residue) and aquatic bryophytes are considered scavenging agents that concentrate elements that have been leached from bedrock and colluvium and are migrating as ions in solution. The oxide residue of stream sediment contains secondary iron and manganese oxides, together with silica and alumina as major components along with the trace elements scavenged from solution. These 
components are extracted from the minus-80mesh sediment using a weak oxalic-acid solution (Alminas and Mosier, 1976). A leachate residue is produced by this extraction process that is a derivative sample of the detrital stream sediment. In areas of low relief, where sulfides and other unstable ore minerals have been removed by chemical weathering, this oxide-rich derivative sample has the following advantages over the minus-80-mesh stream sediment: (1) The level of trace metal content is about an order of magnitude greater in the oxide residue than in the detrital sediment and (2) there is a greater contrast of metal values in the oxide residue than in the detrital sediment. Weakly anomalous metal concentrations that might go unnoticed in the detrital stream sediment are enhanced in the oxide residue because the dilution effects of the detrital sediment are removed.

Aquatic bryophytes were collected beneath the water level from streams and from shallow ponds in swampy areas. Generally, Calliergon cordifolium (Hedw.) Kindb., Calliergon giganteum (Schimp.) Kindb., or Fontinalis duriaei Schimp. were collected at each site. Identification was made by Hansford T. Shacklette, of the U.S. Geological Survey, who followed the nomenclature of Crum, Steere, and Anderson (1973). The bryophytes concentrate elements in solution primarily by absorption (Brooks, 1972). The bryophytes apparently also concentrate certain heavy minerals such as cassiterite (Curtin and others, 1976f) by the entrapment of particulate matter.

Streambank sod was collected beneath the water level from streams in the terrane north of the Tanana River but usually was collected above the water level from streams in the Alaska Range. The streambank sod was not present at many of the sites in the Alaska Range and therefore was not a useful sample medium in this terrane. The streambank sod consists of a mixture of inorganic material ranging in size from silt to fine sand, dead roots, and other pieces of decaying organic material. The element content of the sod consists of elements scavenged from solution primarily by the organic material and the element content of the detrital material.

Copper, zinc, and molybdenum values showed a relatively high positive correlation with the organic content of the sod, which suggests that the quantity of organic material noticeably influences the content of these elements in the sod. A regression analysis-log metal versus organic content-was used to determine the influence of organic content on the variation of copper, zinc, and molybdenum values in the ash of the sod. This type of analysis allows high metal values caused by organic concentration of background amounts of metals to be distinguished from high values derived from a mineralized source. Values from the regression analysis, shown as residuals, were plotted on the geochemical maps for copper, zinc, and molybdenum in the ash of streambank sod.

\section{PREPARATION AND ANALYSIS OF SAMPLES}

Stream sediment samples were air dried and sieved through a minus-80-mesh $(0.2 \mathrm{~mm})$ sieve. A split of the minus-80-mesh material was analyzed for copper, lead, zinc, mercury, and gold by atomic absorption (Ward and others, 1969; Vaughn and McCarthy, 1964) and for arsenic by a colorimetric method (Ward and others, 1963). Another split was analyzed for the other elements by a semiquantitative spectrographic method (Grimes and Marranzino, 1968).

The oxide residue of stream sediment was obtained by leaching a 5-gram split of the minus80-mesh stream sediment with oxalic acid as described by Alminas and Mosier (1976). The residue was analyzed by the semiquantitative spectrographic method of Grimes and Marranzino (1968). With the exception of tin, the reproducibility for the elements of interest in the oxide residue is within the limits of the analytical method used ( \pm 30 percent at the 95 th percentile). The reproducibility for tin shows a variation of as much as 100 percent for individual samples. The analytical results for tin are considered to be usable, however, because the overall distribution pattern of tin did not change noticeably when tin results from repeat analyses were plotted and compared.

Panned concentrates were sieved through a 40-mesh $(0.4 \mathrm{~mm})$ sieve, and the minus-40-mesh fraction was further separated with bromoform into two fractions: a light-mineral fraction composed of minerals having a specific gravity of 2.86 or less and a heavy-mineral fraction composed of minerals having a specific gravity of greater than 2.86. The heavy-mineral fraction was saved and separated magnetically. Magnetite and other magnetic minerals were removed from the heavy-mineral fraction by the use of a hand magnet and a Frantz Isodynamic Magnetic Separator ${ }^{1}$

${ }^{1}$ The use of trade names is for descriptive purposes only and does not constitute endorsement of these products by the U.S. Geological Survey. 
set at 0.2 amperes. This magnetic fraction was saved for analysis. The remaining heavy minerals were again passed through the separator at a setting of 0.6 amperes. The nonmagnetic fraction at this higher setting was saved for analysis and mineralogical examination. This fraction generally contains - in order of relative abundancemuscovite, sphene, zircon, apatite, rutile, anatase, and tourmaline. Ore minerals such as sulfides and cassiterite also occur in this fraction. Both the magnetic and nonmagnetic fractions of panned concentrates were analyzed by semiquantitative spectrographic methods.

The streambank sod was air dried and sieved through a $2-\mathrm{mm}$ stainless steel sieve to remove rock fragments and large pieces of organic litter. The minus-2-mm fraction was ashed, and a split of the ashed sample was resieved through an 80-mesh sieve. The minus-80-mesh material was analyzed for copper, lead, and zinc by atomic absorption, for arsenic by colorimetry, and for the remaining elements by semiquantitative spectrography. A split of the original ashed sample was analyzed for gold by atomic absorption.

The aquatic bryophytes (mosses) were rinsed at the sample site and dried in the field in a cloth bag. The moss was further prepared in the laboratory by hand massaging the dried material to remove remaining sand and silt. The moss samples were then pulverized in a blender and ashed in a muffle furnace at a peak temperature of $500^{\circ} \mathrm{C}$. The ashed samples were analyzed by a semiquantitative spectrographic method for plant materials (Mosier, 1972).

\section{RESULTS}

The geochemical maps and statistical data were generated on a U.S. Geological Survey DEC 10 computer using the STATPAC statistical evaluation library. The geochemical data are plotted on base maps showing generalized geology and the drainage pattern. The elements shown on the maps were selected for their association with known base-metal occurrences and with possible additional undiscovered mineral occurrences.

The results indicate that in the maturely dissected terrane north of the Tanana River, elements apparently migrate in solution from the bedrock and colluvium and enter the streams. The elements are then scavenged by the secondary iron-manganese oxides in the stream sediment, aquatic bryophytes, and the streambank sod beneath the water level. The hydromorphic anomalies produced by the scavenging processes form patterns that outline areas of known mineral occurrences and potential areas of undiscovered resources.

The minus-80-mesh stream sediment is characterized by a lower contrast in element concentration than that observed for panned concentrates and the scavenging agents. The relatively weak, isolated anomalies defined by the streamsediment data illustrate this low contrast. The weak anomalies may be the result of dilution by barren material that constitutes the bulk of the stream sediment and of the selective removal by weathering of sulfides and other unstable ore minerals. The effects of weathering and dilution are overcome, however, by concentrating the heavy-mineral fraction of the stream sediment by panning.

The results also demonstrate that, in the terrane north of the Tanana River, mineral occurrences are more completely defined by a combination of sample media than by any single type of sample. The results further indicate that oxide residue is probably the most useful sample medium in identifying base-metal occurrences. Heavy-mineral concentrates are most useful for detecting occurrences of tin and tungsten mineralization and for delineating anomalous distributions of other metals such as bismuth. Streambank sod and aquatic bryophytes are somewhat less useful than the oxide residue, but they can provide supporting geochemical data. The detrital, minus-80-mesh stream sediment, on the other hand, has only limited use for delineating anomalous distributions of copper, lead, zinc, and tin and is of very little or no use for reconnaissance exploration for metals such as molybdenum, tungsten, and beryllium.

In the Alaska Range, mechanical weathering is the primary destructive process. In this terrane relatively fresh fragments from both country rock and mineralized occurrences are deposited in the streams to produce sediments that reflect the mineralogy of the bedrock in the drainage basins. Therefore, the minus-80-mesh stream sediments and heavy-mineral concentrates adequately define areas of mineral potential in this terrane. Analysis of bedrock collected at a somewhat lower sampling density than the other media aids in defining the chemical composition of the bedrock and in interpretating geochemical results of the stream sediment and panned concentrate sampling. 


\section{REFERENCES}

Starred references indicate those cited in this report.

Alaska Division of Geological and Geophysical Surveys, 1972, Aeromagnetic survey, east Alaska Range, Tanacross, Alaska: Alaska Div. Geol. Geophys. Surveys, Aeromagnetic series, 24 maps, scale $1: 63,360$. - 1973, Aeromagnetic map, Tanacross quadrangle, Alaska: Alaska Div. Geol. Geophys. Surveys, open-file map AOF-11, 1 sheet, scale, 1:250,000.

- 1974, Annual report 1973: Anchorage, Alaska, 59 p.

* Albert, N. R. D., and Steele, W. C., 1976, interpretation of Landsat imagery of the Tanacross quadrangle, Alaska: U.S. Geol. Survey Misc. Field Studies Map MF-767C, 3 sheets, scale 1:250,000.

* Allen, H. T., 1887, Report of an expedition to the Copper, Tanana, and Koyukuk Rivers, in the Territory of Alaska, in the year 1885: Washington, Govt. Printing Office, 172 p.

* Alminas, H. V., and Mosier, E. M., 1976, Oxalic acid leaching of rock, soli, and stream-sediment samples as an anomaly accentuation technique: U.S. Geol. Survey open-file rept., $25 \mathrm{p}$.

Anderson, G. S., 1970, Hydrologic reconnaissance of the Tanana basin, central Alaska: U.S. Geol. Survey Hydrol. Inv. Atlas HA-319, 4 sheets.

Barnes, D. F., 1967, Four preliminary gravity maps of parts of Alaska: U.S. Geol. Survey open-file rept. $5 \mathrm{p}$

* Barnes, D. F., 1976, Gravity map of the Tanacross quadrangle, Alaska: U.S. Geol. Survey Misc. Field Studies Map MF-767B, 1 sheet, scale 1:250,000.

Barnes, D. F., and MacCarthy, G. R., 1964, Preliminary report on tests of the application of geophysical methods to Arctic ground-water problem: U.S. Geol. Survey open-file rept., $32 \mathrm{p}$.

Bates, R. G., and Wedow, Helmuth, Jr., 1953, Preliminary summary review of thorium-bearing mineral occurrences in Alaska: U.S. Geo1. Survey Circ. 202, $13 \mathrm{p}$.

Berg, H. C., and Cobb, E. H., 1967, Metalliferous lode deposits of Alaska: U.S. Geo1. Survey Bu11. 1246, 254 p.

Black, R. F., 1941, Eolian deposits of Alaska: Arctic, v. 4 , no. 2, p. 89-111.

Bostock, H. S., 1952, Geology of the northwest Shakwak Valley, Yukon Territory: Geol. Survey of Canada, Memoir 267, 54 p.

* Brooks, A. H., 1900a, A reconnaissance from Pyramid Harbor to Eagle City, Alaska, including a description of the copper deposits of the upper White and Tanana Rivers: U.S. Geol. Survey 21 st Ann. Rept., pt. 2, p. 331-391. - 1900b, A reconnaissance in the White and Tanana river basins, Alaska, in 1898: U.S. Geol. Survey 20th Ann. Rept., pt. 7, p. 425-494.

, 1916, Antimony deposits of Alaska: U.S.Geol. Survey Bul1. 649, 67 p.

* Brooks, R. R., 1972, Geobotany and biogeochemistry in mineral exploration: New York, Harper and Row, 290 p.

Capps, S. R., 1916, An ancient volcanic eruption in the upper Yukon Basin: U.S. Geol. Survey Prof. Paper 95-D, p. 59-64.
Cederstrom, D. J., 1952, Summary of ground-water development in Alaska, 1950: U.S. Geol. Survey Circ. $169,37 \mathrm{p}$.

Chflders, J. M., Meckel, J. P., and Anderson, G. S., 1972, Floods of August 1967 in east-central Alaska, with a section on Weather features contributing to the floods, by E. D. Diemer: U.S. Geo1. Survey Water-Supply Paper 18 D-A, P. A1-A77.

Churkin, Michael, Jr., 1973, Paleozoic and Precambrian rocks of Alaska and their role in its structural evolution: U.S. Geol. Survey Prof. Paper 740, 64 p.

* Clark, S. H. B., Condon, W. H., Foster, H. L., and Hoare, J. M., 1969, Geochemical data in the Sikonsina Pass area, in Some shorter mineral resource investfgations in Alaska: U.S. Geol. Survey Circ. 615 , p. 21-25.

* Clark, S. H. B., and Foster, H. L., 1969, Geochemical analyses of stream-sediment and rock samples, Tanacross quadrangle, Alaska: U.S. Geol. Survey open-file rept., $12 \mathrm{p}$.

Cobb, E. H., 1970, Antimony occurrences in Alaska: U.S. Geo1. Survey Min. Inv. Res. Map MR-52, 1 sheet, scale $1: 2,500,000$.

1972, Metallic mineral resources map of the Tanacross quadrangle, Alaska: U.S. Geol. Survey Misc. Field Studies Map MF-383, 1 sheet, scale $1: 250,000$.

Cobb, E. H., and Kachadoorian, Reuben, 1961, Index of metallic and nonmetallic mineral deposits of Alaska compiled from published reports of Federal and State agencies through 1959: U.S. Geol. Survey Bull. 1139, $363 \mathrm{p}$.

* Cox, Allan, and Dalrymple, G. B., 1967, Statistical analysis of geomagnetic reversal data and the precision of potassium-argon dating: Jour. Geophys. Research, v. 72, p. 2603-2614.

* Crum, H. A., Steere, W. C., and Anderson, L. E., 1973, A new 1 ist of mosses of North America north of Mexico: Bryologist, v. 76 , no. 1, p. 85-130.

* Curtin, G. C., Day, G. W., O'Leary, R. M., Marsh, S. P., and Tripp, R. B., 1976a, Geochemical maps showing the distribution and abundance of copper in the Tanacross quadrangle, Alaska: U.S. Geol. Survey Misc. Field Studies Map MF-767F, 1 sheet, scale $1: 500,000$.

* Curtin, G. C., Day, G. W., Carten, R. B., Marsh, S. P., and Tripp, R. B., 1976b, Geochemical maps showing the distribution and abundance of molybdenum in the Tanacross quadrangle, Alaska: U.S. Geol. Survey Misc. Field Studies Map MF-767G, 1 sheet, scale $1: 500,000$.

* Curtin, G. C., Day, G. W., O'Leary, R. M., Marsh, S. P., and Tripp, R. B., 1976c, Geochemical maps showing the distribution and abundance of lead in the Tanacross quadrangle, Alaska: U.S. Geol. Survey Misc. Field Studies Map MF-767H, 1 sheet, scale $1: 500,000$.

* Curtin, G. C., Day, G. W., O'Leary, R. M., Marsh, S. P., and Tripp, R. B., 1976d, Geochemical maps showing the distribution and abundance of zinc in the Tanacross quadrangle, Alaska: U.S. Geol. Survey Misc. Field Studies Map MF-767I, 1 sheet, scale $1: 500,000$.

* Curtin, G. C., O'Leary, R. M., and Carten, R. B., 1976e, Geochemical maps showing the distribution and abundance of arsenic and mercury in the Tanacross quadrangle, Alaska: U.S. Geol. Survey Misc. Field Studies Map MF-767J, 1 sheet, scale 1:500,000. 
* Curtin, G. C., Day, G. W., Marsh, S. P., O'Leary, R. M., and Tripp, R. B., 1976f, Geochemical maps showing the distribution and abundance of $t$ in in the Tanacross quadrangle, Alaska: U.S. Geol. Survey Misc. Field Studies Map MF-767K, 1 sheet, scale $1: 500,000$.

* Curtin, G. C., Day, G. W., Marsh, S. P., and Tripp, R. B., $1976 \mathrm{~g}$, Geochemical maps showing the distribution and abundance of beryllium in the Tanacross quadrangle, Alaska: U.S. Geol. Survey MIsc. Field Studies Map MF-767L, 1 sheet, scale 1:500,000.

* Curtin, G. C., Day, G. W., O'Leary, R. M., Marsh, S. P. and Tripp, R. B., 1976h, Composite geochemical map of anomalous copper and molybdenum distribution in the Tanacross quadrangle, Alaska: U.S. Geol. Survey Misc. Field Studies Map MF-767M, 1 sheet, scale $1: 250,000$.

* Curtin, G. C., Day, G. W., O'Leary, R. M., Tripp, R. B., and Carten, R. B., 1976i, Composite geochemical map of anomalous lead and zinc distribution in the Tanacross quadrangle, Alaska: U.S. Geol. Survey Misc. Field Studies Map MF-767N, 1 sheet, scale $1: 250,000$.

Curtin, G. C., Tripp, R. B., O'Leary, R. M., Day, G. W., and Marsh, S. P., 1976, The mobility of metals in the weathering zone applied to reconnaissance geochemical exploration in the Yukon-Tanana Upland, Alaska (abs.): Geol. Assoc. of Canada Programme and Abs., Cordilleran Section, p. 16.

* Dalrymple, G. B., and Lanphere, M. A., 1969, Potassium-argon dating: Principles, techniques, and applications to geochronology: San Francisco, W. H. Freeman and Company, $258 \mathrm{p}$.

* Dusel, C. J., compiler, 1976, Status of land in the Tanacross quadrangle, Alaska: U.S. Geol. Survey Misc. Field Studies Map MF-767D, 1 sheet, scale $1: 250,000$

Ebbley, Norman, Jr., and Wright, W. S., 1948, Antimony deposits in Alaska: U.S. Bur. Mines Rept. Inv. 4173, 41 p.

Ellsworth, C. E., and Davenport, R. W., 1913, Placer mining in the Yukon-Tanana region: U.S. Geol. Survey Bu17. 542, p. 203-222.

1913, Water supply of the Yukon-Tanana region, 1912: U.S. Geol. Survey Bu17. 542, p. 223-278.

Ellsworth, C. E., and Parker, G. L., 1911, Water supply of the Yukon-Tanana region, 1910: U.S. Geol. Survey Bu17. 480 , p. $173-217$.

Fernald, A. T., 1962, Radiocarbon dates relating to a widespread volcanic ash deposit, eastern Alaska, in Geological Survey research 1962: U.S. Geol. Survey Prof. Paper 450-B, p. B29-B30.

1965, Glaciation in the Nabesna River area, upper Tanana River valley, Alaska, in Geological Survey research 1965: U.S. GeōT. Survey Prof. Paper 525-C, p. C120-C123.

1965, Recent history of the upper Tanana River lowland, Alaska, In Geological Survey research 1965: U.S. Geol. Survey Prof. Paper 525-C, p. C124-C127.

* Foster, H. L., 1967, Geology of the Mount Fairplay area, Alaska: U.S. Geol. Survey BuT1. 1241-B, p. B1-B18.

* ___ 1970, Reconnaissance geologic map of the Tanacross quadrangle, Alaska: U.S. Geol. Survey Misc. Geol. Inv. Map I-593, I sheet, scale 1:250,000.
* Foster, H. L., Forbes, R. B., and Ragan, D. M., 1966, Granulite and peridotite inclusions from Prindle Volcano, Yukon-Tanana Upland, Alaska, in Geological Survey research 1966: U.S. Ge07. Survey Prof. Paper 550-B, p. B115-B119.

Foster, H. L., and Keith, T. E. C., 1969, Geology along the Taylor Highway, ATaska: U.S. Geol. Survey Bul1. $1281,36 \mathrm{p}$.

* ___ 1974, UT tramafic rocks of the Eagle quadrangle, east-central Alaska: U.S. Geol. Survey Jour. Research, v. 2, no. 6, p. 657-669.

Foster, H. L., Weber, F. R., Forbes, R. B., and Brabb, E. E., 1973, Regional geology of Yukon-Tanana Upland, Alaska: Arctic Geology Memoir, no. 19, Am. Assoc. Petroleum Geologists.

Freeman, V. L., 1963, Examination of uranium prospects, 1956: U.S. Geo1. Survey Bu11. 1155, p. 29-33.

Gedney, L., Shapiro, L., Van Wormer, D., and Weber, F., 1972, Correlation of epicenters with mapped faults, east-central Alaska, 1968-1971: U.S. Geol. Survey open-file rept., $7 \mathrm{p}$.

Gottfried, David, Jaffe, H. W., and Senftle, F. E., 1959, Evaluation of the lead-alpha age determinations of accessory minerals of igneous rocks: U.S. Geol. Survey Bu1 1. 1097-A, p. 1-63.

Greig, J. A., 1976, Claymore gold placers, Ladue River area, Yukon-Alaska (abs.): Geol. Assoc. of Canada Programme and Abs., Cordilieran Section, p. 21.

* Grimes, D. J., and Marranzino, A. P., 1968, Direct-current arc and aiternating-current spark emission spectrographic ffeld methods for the semiquantitative analysis of geologic materials: U.S. Geol. Survey Circ. 591, 6 p.

* Griscom, Andrew, 1976, Aeromagnetic map and interpretation of the Tanacross quadrangle, Alaska: U.S. Geol. Survey Misc. Field Studies Map MF-767A, 2 sheets, scale 1:250,000.

Hollick, Arthur, 1936, The Tertiary floras of Alaska with a chapter on the geology of the Tertiary deposits by P. S. Smith: U.S. Geol. Survey Prof. Paper 182, $185 \mathrm{p}$.

Holmes, G. W., 1965, Geologic reconnaissance along the Alaska Highway, Del ta River to Tok Junction, Alaska: U.S. Geol. Survey Bu11. 1181-H, p. H1-H19.

, compiler, 1967, Location of pingolike mounds observed from the ground, from aerial reconnaissance, and on aerial photographs in interior Alaska: U.S. Geol. Survey open-file rept., $13 \mathrm{p}$.

Holmes, G. W., Hopkins, D. M., and Foster, H. L., 1966, Distribution and age of pingos of interior Alaska, in International Conference Permafrost Proceedings, Lafayette, Ind., 1963: (U.S.) Nat1. Research Council Pub. 1287, p. 88-93.

1968, Pingos in central Alaska: U.S. Geol. Survey Bu71. 1241-H, p. H1-H40.

Jaffe, H. W., Gottfried, David, Waring, C. L., and Worthing, H. W., 1959, Lead-a1 pha age determinations of accessory minerals of igneous rocks (1953-1957): U.S. Geol. Survey Bu11. 1097-B, p. $65-148$.

Joesting, H. R., 1942, Strategic mineral occurrences in interior Alaska: Alaska Dept. Mines Pamph. 1, 46 p.

Krinsley, D. B., Davies, W. E., Rachlin, J., and Newton, E. G., 1971, Existing environment of natural corridors from Prudhoe Bay, Alaska, to Edmonton, Canada: U.S. Geol. Survey open-file rept., 104 p. 
Lamke, R. D., 1972, Floods in the summer of 1971 in south-central Alaska: U.S. Geol. Survey open-file rept., $88 \mathrm{p}$.

Larsen, E. S., Jr., Gottfried, David, Jaffe, H. W. , and Waring, C. L., 1958, Lead-alpha ages of the Mesozoic batholiths of western North America: U.S. Geol. Survey Bul1. 1070-B, p. 1-33.

Lerbekmo, J. F., and Campbel1, F. A., 1969, Distribution, composition, and source of the White River Ash, Yukon Territory: Canadian Jour. of Earth Sciences, v. 6 , no. 1 , p. $109-116$.

Marvin, R. F., 1974, A tabulation of K-Ar, Rb-Sr, and $\mathrm{Pb}$-alpha ages obtained from materials within the United States (including ATaska and Hawaii) during the years 1956 through 1964: U.S. Geol. Survey open-file report, $174 \mathrm{p}$.

Matzko, J. J., and Freeman, V. L., 1963, Summary of reconnaissance for uranium in Alaska, 1955: U.S. Geol. Survey Bu11. 1155, p. 33-49.

Mertie, J. B., Jr., 1931, A geologic reconnaissance of the Dennison Fork district, Alaska: U.S. Geol. Survey Bul1. 827, 44 p. 1937, The Yukon-Tanana region, Alaska: U.S. Geol. Survey Bul1. $872,276 \mathrm{p}$.

Miller, D. J., Payne, T. G., and Gryc, George, 1959 Geology of possible petroleum provinces in Alaska: U.S. GeoT. Survey BuT?. 1094, $131 \mathrm{p}$

Moffit, F. H., 1932, The Slana district, upper Copper River region, Alaska: U.S. Geol. Survey Bul1. 824 , p. 111-124.

, 1936, Upper Copper and Tanana Rivers: U.S. Geol. Survey Bu77. 868, p. 135-143.

1938, Geology of the Slana-Tok district, Alaska: U.S. Geol. Survey Bul1. 904, 54 p.

, 1944, Mining in the northern Copper River region, Alaska: U.S. Geol. Survey Bul1. 943-B, P. 25-47.

1954, Geology of the eastern part of the Alaska Range and adjacent area: U.S. Geol. Survey Bul1. 989-D, P. 63-218.

* Mosier, E. L., 1972, A method for semiquantitative spectrographic analys is of plant ash for use in biogeochemical and environmental studies: Appl. Spectroscopy, v. 26 , no. 6, p. 636 .

Nelson, A. E., West, W. S., and Matzko, J. J., 1954, Reconnaissance for radioactive deposits in eastern Alaska, 1952: U.S. Geo1. Survey Circ. 348, 21 p.

01 dham, C. H. G., 1954, Gravity and magnetic observations along the Alaska Highway (abs.): Am. Geophys. Unton Trans., v. 35, no. 2, p. 364-365.

, 1958, Gravity and magnetic investigations along the Alaska Highway: Canada Dominion Observatory Pub., v. 21, no. 1, 22 p.

* O'Leary, R. M., McDanal, S. K., McDouga 1, C. M., Day, G. W., Curtin, G. C., and Foster, H. L., 1976, Spectrographic and chemical analyses of geochemical samples and related data from the Tanacross quadrangle, Alaska: U.S. Geol. Survey open-file rept. $76-422,94 \mathrm{p}$.

Péwe, T. L., Burbank, Lawrence, and Mayo, L. R., 1967, Multiple glaciation in the Yukon-Tanana Upland, Alaska: U.S. Geol. Survey Misc. Geol. Inv. Map I-507, 1 sheet, scale 1:500,000.
Péwe, T. L., Hopkins, D. M., and Giddings, J. L., 1965 The Quaternary geology and archaeology of Alaska in Wright, H. E., Jr., and Frey, D. G., eds., The Quaternary of the Untted States--a review volume for the VII Congress of the International Assocjation for Quaternary Research: Princeton, Princeton Univ. Press, p. 355-374.

Prindle, L. M., 1905, The gold placers of the Fortymile, Birch Creek, and Fairbanks regtons, Alaska: U.S. Geo1. Survey Bul1. 251, 89 p.

, 1908, Occurrence of gold in the Yukon-Tanana region: U.S. Geol. Survey Bul 1. 345, p. 179-186.

* $\quad$, 1909, The Fortymile quadrangle, Yukon-Tanana region, Alaska: U.S. Geol. Survey Bul1. 375, 52 p.

* Richter, D. H., 1967, Geology of the upper S1 ana-Mentasta Pass area, southcentral Alaska: Alaska Div. Mines and Minerals Geol. Rept. 30, $25 \mathrm{p}$.

* $\quad 1975$, Geologic map of the Nabesna quadrangle, Alaska: U.S. Geol. Survey Misc. Field Studies Map MF-655A, I sheet, scale 1:250,000.

* Richter, D. H., Albert, N. R. D., Barnes, D. F., Griscom, Andrew, Marsh, S. P., Singer, D. A., 1975, The Alaskan Mineral Resource Assessment Program: Background information to accompany folio of geologic and mineral resource maps of the Nabesna quadrangle, Alaska: U.S. Geol. Survey Circ. 718, 11 p.

Richter, D. H., and Jones, D. L., 1973, Structure and stratigraphy of eastern Alaska Range, Alaska, in Arctic Geology: Am. Assoc. Petr. Geologists, Memoir 19 , p. $408-420$

* Richter, D. H., Lanphere, M. A., and Matson, N. A., Jr., 1975, Granitic plutonism and metamorphism, eastern ATaska Range, Alaska: Geol. Soc. America Bull., v. 86 , no. 6 , p. $819-829$.

St. Armand, Pierre, 1957, Geological and geophysical synthesis of the tectonics of portions of British Columbia, the Yukon Territory and Alaska: Geol. Soc. America Bu11., v. 68, no. 10, p. 1343-1370.

Saunders, R. H., 1966, A geochemical investigation along the Taylor Highway, east central Alaska: Alaska Div. Mines and Minerals Geochem. Rept. 9, $17 \mathrm{p}$.

, 1967, Minera T occurrences in the Yukon-Tanana region, Alaska: Alaska Div. Mines and Minerals Spec. Rept. 2, 58 p.

* Singer, D. A., Curtin, G. C., and Foster, H. L., 1976, Mineral resources map of the Tanacross quadrangle, Alaska: U.S. Geol. Survey Misc. Field Studies Map MF-767E, 1 sheet, scale 1:250,000.

Smith, P. S., 1942, Mineral Industry of Alaska in 1940: U.S. Geol. Survey Bul1. 933-A, p. 1-102.

Spurr, J. E., 1898, Geology of the Yukon gold district, Al aska: 18th Annual Report of the U.S. Geol. Survey 1896-97, pt. 3 , p. 88-392.

Stuiver, M., Borns, H. W., Jr., and Denton, G. H., 1964 , Age of a widespread layer of volcanic ash in the southwestern Yukon Territory: Arctic, v. 17, no. 4, p. 259-261.

Tempelman-KI uit, D. J., 1975, Relationships of plutonic rocks in the Yukon crystal1 ine terrane (abs.): Geol. Assoc. of Canada Programme and ADS., Cordilleran Sec., p. 22-23.

* Tempelman-KIuit, D. J., Gordey, S. P., and Reed, B. C. 1976, Stratigraphic and structural studies in the Pelly Mountains, Yukon Territory, Canada Geol. Survey Paper 76-1A, p. 97-106. 
* Tempelman-Kluit, D. J., and Wanless, R. K., 1975, Potassium-argon age determinations of metamorphic and plutonic rocks in the Yukon crystalline terrane: Canadian Jour. Earth Sci., v. 12, no. 11, p. 1895-1909.

Thompson, C. E., Nakagawa, H. M., and Van Sickle, G. H., 1968, Rapid analysis for gold in geologic materials, in Geological Survey research 1968: U.S. Geol. Survey Prof. Paper 600-B, p. B130-B132.

* Tripp, R. B., Curtin, G. C., Day, G. W., Karlson, R. C. and Marsh, S. P., 1976, Maps showing mineralogical and geochemical data for heavy mineral concentrates in the Tanacross quadrangle, Alaska: U.S. Geol. Survey Misc. Field Studies Map MF-7670, 2 sheets, scale 1:500,000.

U.S. Geological Survey, 1898, Map of Alaska showing known gold-bearing rocks, with descriptive text containing sketches of the geography, geology, and gold deposits and routes to the fields, 44 p., 1 sheet.

, 1899, Maps and descriptions of routes of exploration in Alaska in 1898, with general information concerning the Territory: U.S. Geol. Survey Spec. Pub., 138 p.

1963, Geological Survey research 1963, summary of investigations, prepared by members of the Conservation, Geologic, and Water Resources Divisions: U.S. Geo1. Survey Prof. Paper 475-A, p. AI-A300.

, 1966, Geological Survey research 1966: U.S. Geol. Survey Prof. Paper 550-A, p. A1-A385.

* Vaughn, W. W., and McCarthy, J. H., Jr., 1964, An instrumental technique for the determination of submicrogram concentrations of mercury in soils, rocks, and gas, in Geological survey research 1964: U.S. Geo1. Survey Prof. Paper 501-D, D. D123-D127.
* Wahrhaftig, Clyde, 1965, Physlographic divisions of Alaska: U.S. Geol. Survey Prof. Paper 482, 52 p.

* Ward, F. N., Lakin, H. W., and Canney, F. C., 1963, Analytical methods used in geochemical exploration by the U.S. Geological Survey: U.S. Geol. Survey Bul1. 1152, $100 \mathrm{p}$.

* Ward, F. N., Nakagawa, H. M., Van Sickle, G. H., and Harms, T. G., 1969, Atomic absorption methods useful in geochemical exploration: U.S. Geol. Survey Bu?1. $1289,45 \mathrm{p}$.

* Wasserburg, G. J., Eberlein, G. D., and Lanphere, M. A., 1963, Age of the Birch Creek Schist and some batholithic intrusions in Alaska (abs.): Geo1. Soc. America Spec. Paper 73, p. 258-259.

Wedow, Helmuth, Jr., White, M. G., and others, 1954, Reconnaissance for radioactive deposits in east-central Alaska 1949: U.S. Geol. Survey Circ. 335, Chap. D, p. 10-12.

Wedow, Helmuth, Jr., Killeen, P. L., and others, 1954, Reconnaissance for radioactive deposits in eastern interior Alaska, 1946: U.S. Geol. Survey Circ. 331, $36 \mathrm{p}$.

White, M. G., Nelson, A. E., and Matzko, J. J., 1963, Radiometric investigations along the Taylor Highway and part of the Tanana River, Alaska: U.S. Geol. Survey Bu11. 1155, p. 77-82.

Worl, R. G., Van Alstine, R. E., and Heyl, A. V., 1974, Fluorite in the United States, exclusive of Hawail: U.S. Geo1. Survey Min. Inv. Res. Map MR-60, 1 sheet, scale $1: 3,168,000$ and $1: 12,672,000$. 